Social Security Driven Tax Wedge and its Effects on Employment and Shadow Employment

Marek Góra (Warsaw School of Economics and CASE)

Oleksandr Rohozynsky (CASE)

Irina Sinitsina (CASE)

Mateusz Walewski (CASE)

Berlin, August 2008 


\section{DP3 - Social security driven Tax wedge and its effects on employment and shadow employment.}

\section{Marek Góra, Oleksandr Rohozynsky, Irina Sinitsina, Mateusz Walewski}

1. Introduction

2. Social security and taxes in Russia and Ukraine - general review of current situation and last reforms

2.1 Economic Backgroud - general situation in CIS countries.

2.2 Financing social security expenditure in CIS and changes driven by the financial problem.

2.3 Last reforms of tax and social contributions system and current situation in Russia and

Ukraine.

2.3.1 Payroll taxes in Ukraine.

2.3.2 Payroll taxes in Russia.

3. The relationship between social security net, taxes, employment and shadow employment

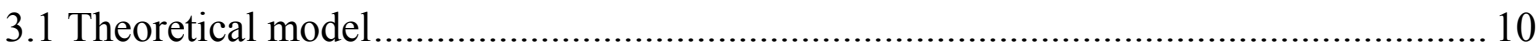

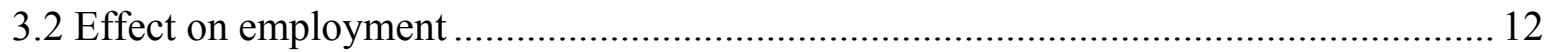

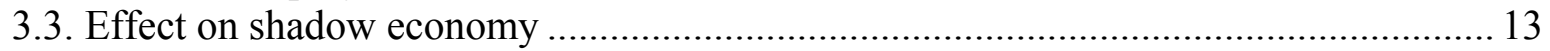

4. Tax wedge and employment - estimation of possible results of tax wedge shift for

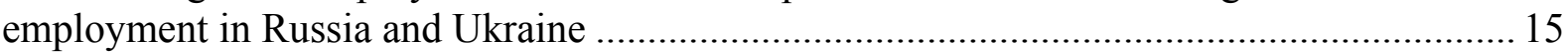

5. Tax wedge and shadow employment - estimations for Ukraine ................................... 20

6. Shadow employment, wages and access to social security in Ukraine and Russia ............ 25

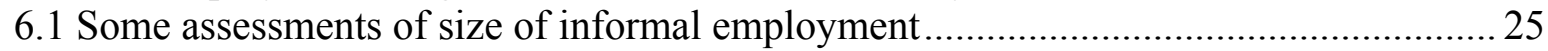

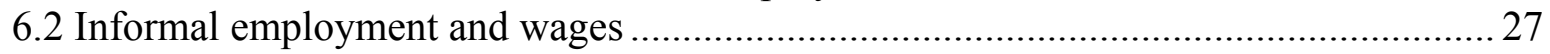

6.3 Impact of being informally employed on access to social security benefits and EPL ... 28

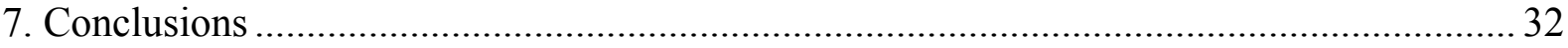

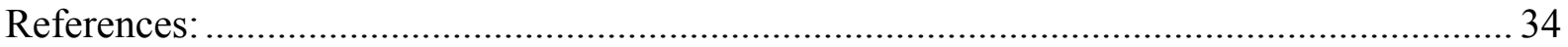




\section{Introduction}

The aim of this paper is to analyse possible directions and magnitudes of the relationship between the social security driven tax wedge, employment and shadow employment in Russia and Ukraine. These subjects have been studied earlier both for these two countries and for a broader set of CIS (Commonwealth of Independent States) countries by a number of researchers (Johnson et al 1999, Kaufman\&Kaliberda 1997, Mel'ota et all 2001a, 2001b, Rutkowski 2006, World Bank 2000 and 2006). Most of the results suggest a limited positive relationship between the size of the tax wedge and shadow employment.

The first specific feature of this paper, however, is that it draws heavily on earlier, particularly local, literature on the subject that is probably not familiar to the international reader. It discusses the relationship between the shape of social security systems in these countries and the resulting tax wedge. It provides a reader with an up-to-date review of current payroll tax systems in both countries and provides in-depth analyses of the social and institutional background for the development of the tax wedge driven shadow employment in the analysed countries. Last but not least, it also discusses the possible negative social consequences of being engaged in shadow employment for employees as such.

A separate feature of the paper is that it puts significant pressure on the heterogeneity of the labor force from the point of view of education (skills) and hence, expected productivity. Most of the analyses below (if only applicable) differentiate between high-skilled and lowskilled workers in order to take into account the tax wedge effects on employment levels and that the fact that shadow employment can vary for different educational (skills) strata of the population. It seems that the results of our analyses strongly support such a view.

On the other hand, however, the broad coverage of the analysis provided has been achieved at the expense of its depth. Therefore, if answering the questions of interest is not possible (mostly due to insufficient data), we try to open areas for further research.

The paper is organised as follows: the first section presents a summary of the economic and institutional background for development of the current size and structure of the socially driven tax wedge in both countries. The second section presents some theoretical considerations on the relationship between the social protection system, tax wedge, nonemployment and finally, shadow employment. The third section contains an attempt to econometrically estimate the magnitude of the possible relationship between the tax wedge and total employment rates in both countries. In the fourth section, the authors try to discover the mechanism of influence of the last reform of the Ukrainian payroll tax system on the structure and size of shadow employment in the country. The last analytical section closes the circle leading the reader back from shadow employment to wages and finally to the issue of access to social security institutions. The last section concludes. 


\section{Social security and taxes in Russia and Ukraine - general review of current situation and last reforms}

\subsection{Social and Economic Background - general situation in CIS countries}

By the end of the 1980's, the countries of the "Soviet Block" (Eastern European countries and the Soviet Union) had Social Safety Nets (SSN hereafter) with the most extensive coverage and costs. For example, the SSN in the United States consists of about 80 mean-tested federal programs that provide some cash (TAFT program), in-kind (housing and food), and healthcare assistance (Medicaid) to low-income individuals and households (Lindert 2005), in addition to the government pension program. The total cost of welfare programs in the US is only about $16 \%$ of GDP (UNECE 2005). Western Europe has a more generous and expensive SSN system that includes government-funded or obligatory health insurance, higher pension and unemployment benefits, early retirement, and government assistance for education. This system is more expensive, and European counties spend about $24 \%$ of GDP on the safety net. The SSN of the former Soviet Block countries provided free healthcare and education (including higher education) to everyone, and the costs of other services, such as childcare, vacations, etc. were greatly reduced by price equalization mechanisms. B. Milanovic (1997) showed, in his book, that social transfer constituted about $19 \%$ of personal income in a typical socialist economy, while it accounted for only $14 \%$ in a typical market economy. This difference may be even larger because some benefits provided in-kind or through discounts by the state enterprises to their workers can not be captured by such a simple comparison. The pensions were relatively generous and the retirement age was around 55 for females and 60 for males; in addition, retirees received a package of discounted or free services, such as housing, phone, and other necessities. Because there was no unemployment, unemployment benefits were non-existent in these countries. The cost of the SSN was huge, but was largely carried by the state-owned enterprises and not by the state budgets.

At the end of 1980's and beginning of the 1990's, the Soviet Block countries began transitioning their economies from the planned to the market economy system. It was obvious that it would be impossible to make the transition without transforming the SSN because price controls and the heavy SSN burden on enterprises were not compatible with the market economy. However, even when the SSN became the government's responsibility, it had to be reformed because (1) it did not match new tasks and poverty profiles, and (2) the economic slowdown accompanying the transition put constraints on government expenditures.

The countries of the FSU (Former Soviet Union) took the path of slow reform. They experienced a longer (more than 6 years) and deeper (60-80\% of GDP cumulative decline) economic slowdown. Due to this slowdown, the average tax revenues in the CIS countries fell from 28\% of GDP in 1992 to 22\% of GDP in 1998, and some countries with a slower transition such as Georgia, Kyrgyzstan or Tajikistan experienced a drop in revenues to less than 15\% of GDP (World Bank 2000). The transition to the market economy forced governments to reduce some budget functions such as direct subsidies to the national economy, but the SSN systems remained almost unchanged. It seems that FSU countries were caught in the political lock-up that did not allow cutting any social benefits that are provided to the whole population. Most of the countries (except Russia and Kazakhstan, which have 
significant incomes from crude oil extraction) ${ }^{1}$ constantly run significant budget deficits in order to finance government obligations.

The labor market transformation in CIS countries differed from the transformation in countries of Eastern Europe (current "new" EU states). Despite massive drops in GDP, unemployment in CIS countries remained at relatively low levels. During the period 19901994, average decline of GDP in the CIS countries was around $-11 \%$, while decline in employment was only $-1 \%$ (compare to the $-3 \%$ and $-4 \%$ respectively in CEE (Central and Eastern Europe) countries) (Nesporova 2002). During the periods of 1994-1998 and 19982004 , the figures were $(-0.2 \%,-0.3 \%)$ and $(+4.5 \%,+0.3 \%)$ respectively. Only countries involved in armed conflict, such as Armenia, Georgia, and Moldova, experienced a sharp decline in employment. The real adjustment was felt through the large drop of real wages, which declined dramatically in the CIS region during the transition. On average, they still remain lower than in the pre-transition period.

Because of the reluctance to extensively reduce labor during transition in the CIS countries, a drop in unemployment was not the major precondition to reduce poverty in these countries. The problem, however, was that low-income employees were first to experience the onset of massive arrears in wages, pensions and other benefits. (World Bank 2000). By the end of the 1990's, there emerged new social groups prone to poverty: families of officially employed persons on unpaid or partially paid leave, public workers, small farmers and rural business owners (Ackland\&Falkingham 1997). The working poor accounted for about half of the poor in Russia where about $87 \%$ of poor lived in families where one or several members were employed (Ovcharova 2003). In Ukraine, about $78 \%$ of poor families had at least one working member in 1999 (Libanova 2001).

The economic decline during the initial stage of transition sharply affected the more educated groups. A World Bank study of poverty in the CIS region in 2000 (World Bank 2000) showed that contrary to OECD countries, the competitive advantages of higher education in the CIS were fairly low: not all the qualified workers in the CIS could find positions adequate to their qualifications. However, later studies found that poverty is negatively correlated with education. Buitano (2000) showed that in Ukraine, a higher level of education of the head of the household was significantly and negatively correlated with poverty incidence.

The highest risk of becoming poor in CIS countries is faced by families with a large number of dependents (children, disabled and pensioners), supported by one working member. The World Bank study (2000) found that children are especially vulnerable to poverty in Central Asian CIS, and having a child dramatically reduces the chances of escaping poverty in European CIS.

Despite common perceptions, the elderly and pensioners are not at a higher risk for falling into poverty than the rest of the CIS population. Only pensioners unable to work and living in a single-person household would almost certainly fall into poverty. The low pension age prevailing in most CIS countries explains this phenomenon. Many pensioners continue to work after retirement and the pension acts as a supplementary payment sufficient to bring their income above the poverty line. The World Bank (2000) found that the risk of poverty for working pensioners is only about one third of the average poverty risk in Russia.

\footnotetext{
${ }^{1}$ This is true only for the period after 2000. As concerns the early and mid-1990's - vast deficits in SSN budgets and unpaid benefit mandates were typical in these countries as well.
} 


\subsection{Financing social security expenditure in CIS and changes driven by the financial problem}

The social welfare system in the CIS countries did not change significantly from the universal social welfare system inherited from the USSR. The system remains very poorly oriented towards supporting the poor. Social assistance programs remain aimed at providing services or supplementary payments to certain groups of the population (elderly, children, disabled), and poverty reduction, an urgent task, is not at the top of the policy agenda. Inflation, growth, and the budget deficit have higher priority. Additionally, programs aiming at poverty alleviation are poorly addressed and the task of poverty reduction is of least importance.

Reacting to the dramatic change in the structure of expenditures, and in order to retain the Soviet era system of special rates, the governments of the CIS countries introduced a large number of subsidies or discounts, often provided in-kind. For example, until 2005, Russia kept 156 types of subsidies and social payments that were directed to 236 different population groups. Almost $70 \%$ of the Russian population received at least one of the welfare benefits (CSR 2000). At the end of the 1990's, about 3\% of GDP in Moldova was distributed among more than 100 different subsidies and discounts. Armenia and Ukraine had the same situation (Fox 2003). As a result, the number of beneficiaries of these assistance programs became enormously high, while the size of the benefits gradually decreased due to lack of financing.

Despite the significant expenditures on subsidies and discounts, these programs were very severely underfinanced. It was estimated by the researchers at the Center of Strategic Research (Russia) that the financing needed for the subsidies established by federal law in Russia exceeded $15 \%$ of GDP in 1999. In order to improve monitoring and targeting of these social benefits, Russia monetized the in-kind benefits in 2005 (Federal Law \#122). However, the monetization of the benefits triggered a strong negative social reaction and the reform of these social benefits in order to reduce their cost did not begin.

The apparent problem of non-payment of social benefits, resulting from the huge difference between the required expenditures and available revenues, was partially resolved by a decrease in the real amounts of the payments due to high inflation. Until the beginning of the 21 st century, the payments were not automatically indexed with inflation, but rather revised on irregular bases. As a result, by 2003-2004, the welfare payment became merely symbolic in most of the countries. For example, the social benefits in Russia amounted to about $6 \%$ of the average wage, and in Ukraine and Azerbaijan to about 3-4\% of the average wage.

The largest social welfare item outside the state budget in FSU countries is pensions, reaching $7-12 \%$ of GDP. Despite being the largest expenditure item, due to lack of funding, the actual pension benefits paid were considered only valuable additional income for working pensioners, and alone were not able to provide income sufficient to stay out of poverty. For example, the universal pension in Georgia in 2000 was only $23 \%$ of the living wage, and in Ukraine the average pension was only $36 \%$ of the living wage in 2003 . Following the example of CEE countries, the CIS countries began pension reform, introducing a multi-tier (mandatory and voluntary funds) pension system. However, these countries are still at the beginning of the process and the new systems' are only expected to have an impact in 15-20 years. 


\subsection{Recent reforms of tax and social contributions system and current situation in Russia and Ukraine}

\subsubsection{Payroll taxes in Ukraine.}

Currently, Ukraine has a rather complex system of four separate social insurance programs that collect payroll taxes. Each program has its own tax rates, its own independent administration and operation, and its own regulation. The list is comprised of: pension insurance, unemployment insurance, temporary disability insurance, and industrial accident insurance. The payroll taxes collected by these insurance funds are all imposed on the same base (payrolls) but they have an income ceiling. Thus, rates are levied only on up to seven times the average wage in the country. ${ }^{2}$ In total, the combined tax rate for all programs often exceeds $40 \%$, depending on the risk of industrial accidents, and as Table 2.1 shows, the vast bulk is the employer's share. The single largest contribution is to the pension insurance fund $(33.2 \%)$.

Table 2.1: Tax Rates of Social Insurance Programs in Ukraine (as a Percentage of Employee Wage Income)

\begin{tabular}{|l|l|c|c|c|c|}
\hline Contributions(*) & $\begin{array}{l}\text { Pension } \\
\text { Insurance }\end{array}$ & $\begin{array}{c}\text { Unemployment } \\
\text { Insurance }\end{array}$ & $\begin{array}{c}\text { Temporary } \\
\text { Disability } \\
\text { Insurance (2) }\end{array}$ & $\begin{array}{c}\text { Industrial } \\
\text { Accident } \\
\text { Insurance. }\end{array}$ & Total \\
\hline Employer & 31.8 & 1.3 & 2.9 & $1.5(4)$ & 37.5 \\
\hline Employee & $1.0 / 2.0(1)$ & 0.5 & $0.5 / 1.0(3)$ & --- & $2-3.5$ \\
\hline Total & $32.8-33.8$ & 1.8 & $3.4-3.9$ & 1.6 & $39.5-41$ \\
\hline
\end{tabular}

(*) Rates as established in the 2006 budget of Ukraine.

(1) Includes sickness, maternity and funeral insurance. The average total rate for the pension fund alone is $33.8 \%$ of wages. (2) An average weighted rate. The rate the employer pays varies from $0.66 \%$ to $13.6 \%$ depending on the degree of hazardous risk level. Overall, there are 67 different risk categories and some 30 rates. Moreover, there is more variety in alternatives for companies that employ the disabled, working pensioners, and farmers. Thus, there is a wide range of variations in individual liability even within a single company. This type of complexity adds an extra burden to the withholders (and taxpayers) and makes collection monitoring and control more difficult.

(3) $1.0 \%$ of gross taxable income under UAH $150 ; 2.0 \%$ of gross taxable income over UAH 150.

(4) $0.5 \%$ for wages below the subsistence threshold; $0.1 \%$ for wages above the subsistence threshold.

Sources: MoF, MoL, Budget 2006, Ukraine: Creating Fiscal Space for Growth: A Public Finance Review. World Bank Report No. 36671 - UA. September 14, 2006

Above that, there exists a system of simplified taxation (STS) for small business that substitutes the general payroll taxation. The idea behind having such a system in Ukraine was to bring to light the small businesses operating in the shadow economy. The STS was instituted by the Presidential Decree in July 1998. The small businesses falling under the Decree include the following:

- physical persons or individual entrepreneurs with annual gross turnover not exceeding UAH 500,000 and employing not more than ten persons, including family members;

- legal entities (firms) with an average annual number of employees not exceeding 50 persons and with annual gross turnover not exceeding UAH 1,000,000.

\footnotetext{
${ }^{2}$ The cap is established as seven times the average wage in the country. The monthly average wage in 2005 was UAH 806 , so the ceiling in that year was UAH 5,642. This ceiling is set in the annual Budget Law.
} 
Under STS, the taxpayer (either individual or a firm) is to choose one of the following rates for the unified tax:

- $6 \%$ of the gross turnover (less excise taxes) plus VAT, or

- $10 \%$ of the gross turnover (less excise taxes) with VAT included into the unified tax (see Table1.2)

The tax collected from individual entrepreneurs is distributed according to the following scheme:

- to local government budgets - $43 \%$;

- to the pension fund $-42 \%$;

- to social insurance funds $-15 \%$ (including $4 \%$ to the employment fund).

- Taxes collected from firms are distributed in a similar way, with the exception of local budgets receiving $23 \%$, and the remaining $20 \%$ going to the central government budget.

Table 2.2 The Simplified Tax System (STS) in Ukraine

\begin{tabular}{|l|l|l|l|l|}
\hline Options & $\begin{array}{l}\text { Subject of } \\
\text { taxation }\end{array}$ & Eligibility criteria & Base & Tax Rate \\
\hline $\begin{array}{l}\text { The unified } \\
\text { Tax }\end{array}$ & $\begin{array}{l}\text { Legal entities } \\
\text { (firms) }\end{array}$ & $\begin{array}{l}\text { Annual gross (last 12 months) turnover } \\
\text { does not exceed UAH 1,000,000; firm } \\
\text { does not have more than 50 employees. }\end{array}$ & $\begin{array}{c}\text { Gross } \\
\text { Turnover }\end{array}$ & $\begin{array}{l}\text { 6\%; but not exempt } \\
\text { from VAT. }\end{array}$ \\
\cline { 2 - 5 } & $\begin{array}{l}\text { Physical persons or } \\
\text { "individual } \\
\text { entrepreneurs" } \\
\text { (individuals) }\end{array}$ & $\begin{array}{l}\text { Annual gross turnover (last 12 months) } \\
\text { does not exceed UAH 500,000; } \\
\text { entrepreneur does not have more than } \\
10 \text { employees. }\end{array}$ & $\begin{array}{l}\text { Gross } \\
\text { Turnover }\end{array}$ & $\begin{array}{l}\text { 6\%; but not exempt } \\
\text { from VAT }\end{array}$ \\
\hline Fixed Tax & $\begin{array}{l}\text { Physical persons } \\
\text { (individuals) }\end{array}$ & $\begin{array}{l}\text { Annual turnover (last 12 months) does } \\
\text { not exceed UAH 119,000; do not have } \\
\text { more than 5 employees. }\end{array}$ & -------- & $\begin{array}{l}\text { Patents vary from } \\
\text { UAH 20-200 per } \\
\text { month. }\end{array}$ \\
\hline $\begin{array}{l}\text { Other (Trade } \\
\text { patents, fees } \\
\text { and permits) }\end{array}$ & $\begin{array}{l}\text { Levied on legal } \\
\text { entities and } \\
\text { individuals. }\end{array}$ & $\begin{array}{l}\text { Small firms as assed by local } \\
\text { governments (LG) }\end{array}$ & $\begin{array}{l}\text { Various amounts } \\
\text { (assessed by LG). }\end{array}$ \\
\hline
\end{tabular}

The employees of the firms that opted for STS pay the same payroll taxes as those working under a general tax scheme:

- $1-2 \%$ to the pension fund;

- $0,5 \%$ to the employment fund;

- $0,5-1 \%$ to the social insurance fund;

- $13 \%$ PIT (flat rate).

There is evidence, albeit mixed, that the STS has encouraged SMEs registration and entry. However, the current system design has led to substantial abuses, inefficiencies, and an erosion of the regular tax base in the following ways (World Bank 2006):

- it created incentives for legal and illegal migration from the regular tax system, which generated revenue losses for the budget in all major taxes (payroll taxes, the PIT, the VAT, and, more marginally, the CIT);

- it distorted taxpayer behavior in inefficient ways for the economy, potentially lowering productivity in the economy (e.g., firms fragment their operations into smaller firms to meet the threshold ${ }^{3}$, losing economies of scale; and production and sales are kept below thresholds hampering output growth); and

\footnotetext{
${ }^{3}$ Anecdotal evidence suggests that businesses break their operation into pieces and use other schemes to fit the requirements of the system (Creating Fiscal Space for Growth, p.17).
} 
- it introduced substantial horizontal (and vertical) inequalities to the system (e.g., an individual working as a "consultant" under the STS may pay significantly lower taxes than an individual with the same type of job description at a firm and the same level of income under the regular income tax system).

\subsubsection{Payroll taxes in Russia.}

The Unified Social Tax (UST) was introduced in Russia in December 2001, replacing insurance contributions paid by employers to four separate insurance funds - the pension fund, the social insurance fund, the federal obligatory medical insurance fund, and the territorial medical insurance funds. Later, the UST was included into Chapter 24 of the Tax Code.

Initially, the UST basic rate for legal entities was set at $35.6 \%$, and its effective rate - at $29 \%$. Beginning in 2005, these were reduced to $26 \%$ and $24 \%$ accordingly. UST is a regressive tax: the rates are significantly lower for annual salaries exceeding RUR 600,000 (see Table 1.3). The whole of the UST is paid by the employer. In 2007, the UST was distributed according to the following scheme:

- $20 \%$ - to the federal budget for pension financing;

- $2.9 \%$ - for social insurance;

- $3.1 \%$ - for medical insurance.

For individual entrepreneurs, the UST rate is set at $10 \%$ of the tax base $(7.3 \%$ to the federal budget for pension financing and $2.7 \%$ for medical insurance).

Table 2.3 The Unified Social Tax (UST) system in Russia.

\begin{tabular}{|c|c|c|c|c|c|c|c|c|}
\hline & & UST & es sin & Janu & y 1st, & 07 & & \\
\hline & & & & l entities & & & & \\
\hline Tax base, annual, & Federal budget (pensions) & Socia & ince fund & & igatory medi & 1 insurance & & Total \\
\hline for each employee & & & udget) & Federal (fe & ral budget) & Ter & rial & \\
\hline $\begin{array}{l}\text { Less than RUR } \\
28,0000\end{array}$ & $20,0 \%$ & & & & & & & $26,0 \%$ \\
\hline $\begin{array}{l}\text { RUR 28,0001 - } \\
\text { RUR } 600,000\end{array}$ & $\begin{array}{c}\text { RUR } 56,000+7,9 \% \text { of } \\
\text { the sum exceeding RUR } \\
280,000\end{array}$ & $\begin{array}{l}\text { RUR } \\
\text { the sur }\end{array}$ & $\begin{array}{l}+1,0 \% \text { of } \\
\text { eding RUR } \\
000\end{array}$ & $\begin{array}{r}\text { RUR 3,08 } \\
\text { the sum ex } \\
28\end{array}$ & $\begin{array}{l}+0,6 \% \text { of } \\
\text { eding RUR } \\
00\end{array}$ & $\begin{array}{r}\text { RUR 5,60 } \\
\text { the sum ex } \\
28\end{array}$ & $\begin{array}{l}0,5 \% \text { of } \\
\text { ding RUR } \\
00\end{array}$ & $\begin{array}{c}\text { RUR } 72800+10,0 \% \text { of } \\
\text { the sum exceeding RUR } \\
280,000\end{array}$ \\
\hline $\begin{array}{l}\text { Over RUR } \\
600,000\end{array}$ & $\begin{array}{c}\text { RUR } 81,280+2,0 \% \text { of } \\
\text { the sum exceeding RUR } \\
600,000\end{array}$ & & 1,320 & RUI &, 000 & RU & 200 & $\begin{array}{c}\text { RUR } 104,800+2,0 \% \text { of } \\
\text { the sum exceeding RUR } \\
600,000\end{array}$ \\
\hline & & & Individ & entreprene & & & & \\
\hline Tax base, annual & Federal budget (pel & ons) & & gatory medi & 1 insurance $f$ & & & Total \\
\hline & & & & & Ter & orial & & \\
\hline $\begin{array}{l}\text { Less than RUR } \\
28,0000\end{array}$ & $7,3 \%$ & & & & & & & $10,0 \%$ \\
\hline $\begin{array}{l}\text { RUR 28,0001 - } \\
\text { RUR } 600,000\end{array}$ & $\begin{array}{r}\text { RUR } 20,440+2,7 \% \\
\quad \text { exceeding RUR } 28\end{array}$ & $\begin{array}{l}\text { he sum } \\
000\end{array}$ & $\begin{array}{r}\text { RUR 2,24 } \\
\text { the sum ex } \\
28\end{array}$ & $\begin{array}{l}+0,5 \% \text { of } \\
\text { eding RUR } \\
00\end{array}$ & $\begin{array}{r}\text { RUR 5,32 } \\
\text { the sum ex } \\
28\end{array}$ & $\begin{array}{l}+0,4 \% \text { of } \\
\text { eding RUR } \\
000\end{array}$ & $28,000+$ & $\begin{array}{l}6 \% \text { of the sum exceeding } \\
\text { RUR } 280,000\end{array}$ \\
\hline $\begin{array}{l}\text { Over RUR } \\
600,000 \\
\end{array}$ & $\begin{array}{r}\text { RUR } 29,080+2,0 \% \\
\text { exceeding RUR } 60 \\
\end{array}$ & $\begin{array}{l}\text { he sum } \\
000\end{array}$ & RUI & 3840 & RU & 6600 & $\begin{array}{r}\text { RUR3 } \\
\text { ex }\end{array}$ & $\begin{array}{l}520+2,0 \% \text { of the sum } \\
\text { eding RUR } 600,000\end{array}$ \\
\hline
\end{tabular}

The major difference between Ukraine and Russia is not in the sizes of the tax wedge (in fact, these are very close), rather the difference between the two countries is that in Ukraine, 'social insurance contributions' are insurance premiums (insuring against risks) rather than taxes as such and are not included in the tax base, while in Russia, these payments are taxes paid directly to the government that administers the corresponding funds. 
For Russian SMEs, there exists a simplified taxation regime (either STS or unified tax on imputed income) established in 1998 and introduced into Part 2 of the Tax Code. The unified tax replaced most of the taxes (with the exception of the PIT) levied on SMEs. Generally, SMEs pay taxes using the following rates:

- $6 \%$ of total earnings, or

- $15 \%$ of total earnings less expenses, or

- $15 \%$ of imputed income.

Individual entrepreneurs not using hired labor make a fixed-size payment to the pension fund. The size of this payment is determined annually by the government. Currently, its minimal monthly size is RUR 150 .

The results of several entrepreneur opinion surveys indicate that the STS, in general, is not totally rejected by small businesses. Moreover, a survey conducted in three regions in 2001 by the Resource Center for Small Entrepreneurship shows that the STS is somewhat more acceptable for the small business as compared to the general taxation system. 


\section{The relationship between the social security net, taxes, employment and the shadow employment}

\subsection{Theoretical model}

In order to run the analysis of the relationship between social safety nets, the tax wedge and employment, we would like to introduce a simple econometric model. Let us assume that we have an economy with $N$ individuals, and:

(1) Every individual in the country can consume either goods $c$ or leisure $l$.

(2) Every individual has the same concave and twice differentiable utility function $U(c, l)$ that this individual tries to maximize.

(3) Every individual has an income $I$, which consists of government transfers and the labor income, and is equal to the time the person works, multiplied by his/her wage: $i=b+w^{*}(T-l)$.

(4) Each individual maximizes his/her utility given this budget constraint. Assuming there is no savings and the whole income is consumed, the constraint is $c=i$. The general solution to this problem is to choose the level of work at the point where marginal rate of substitution is equal to the wage rate. Assuming for simplicity that utility is linear in consumption, the utility-maximizing amount of work is given by: $\partial U(c, l) / \partial l=-w$.

In order to introduce a social welfare system into this economy, we have to make at least two critical assumptions about individuals in the country.

(5) The individuals in the country have different abilities. For simplicity, we can assume that $\lambda$ percent of population has high abilities, able to earn wage $a_{H}$, and $(1-\lambda)$ has low abilities and earns the wage $a_{L}$.

(6) The individuals with low ability can not generate labor income sufficient to bring their consumption to some minimum acceptable social standard of consumption (subsistence level) $M$.

Therefore, the government has to step in and supplement the income of the low-ability individuals to the level $Z$ (which may be equal to or different from $M$, depending on the generosity of the system), developing a simple safety net.

Finally, we assume that the government is interested in minimizing expenditures on the social safety net given the necessity to bring the income of all individuals in the country to a level at or above $Z$. We also assume that an individual does not consider this government goal when making his/her decision. In this case, the total cost of the Social Security Net in equilibrium is determined by the government's ability to monitor individual abilities and earnings.

If the government is able to clearly observe individual abilities and earnings, the total expenditures for the social safety net will be minimized at the level $E=N^{*} \lambda *\left(Z-a_{L} *\left(T-l\left(a_{L}\right)\right)\right.$. Coate and Besley (1992) show in their article that under such conditions, the government will have to pay only $Z-a_{L} *\left(T-l\left(a_{L}\right)\right)$ in social benefits to the low ability individuals and will not pay any social benefits to the individuals with high abilities. 
If the government is not able to observe abilities, even if it is able to perfectly observe the level of wage earnings, the theory leads to the conclusion that high-ability individuals may modify their working behavior in order to receive the benefit $Z-a_{L} *\left(T-l\left(a_{L}\right)\right)$. Since the highability people are more productive, it will take them less time to work for the wage-income generated by low-ability people, (only $a_{L} *\left(T-l\left(a_{L}\right)\right) / a_{H}$ hours). The high ability people will alter their income if their utility from working less with total income at level $\mathrm{Z}$ will be higher than utility from higher consumption and higher work $U\left(Z,\left[\left(a_{H-} 1\right) T+l\left(a_{L}\right)\right] / a_{H}\right) \geq U\left(a_{H}^{*}(T-\right.$ $\left.\left.l\left(a_{H}\right)\right), l\left(a_{H}\right)\right)$.

Coate and Besley (1992) show that in this situation, the government has two choices that minimize the expenditures for the welfare system. First, they can offer the benefits of $Z$ $a_{L} *\left(T-l\left(a_{L}\right)\right)$ to people with wage income $a_{L} *\left(T-l\left(a_{L}\right)\right)$ and smaller benefit $B$ that will satisfy criteria $U\left(B,\left[\left(a_{H-}\right) T+l\left(a_{L}\right)\right] / a_{H}\right)=U\left(a_{H} *\left(T-l\left(a_{H}\right)\right), T-l\left(a_{H}\right)\right)$ to the population with income above $Z$. The total cost of the welfare system will go up to $E_{2}=N^{*}\left(\lambda^{*}\left(Z-a_{L}^{*}\left(T-l\left(a_{L}\right)\right)\right)+(1-\right.$ $\left.\lambda)^{*} B\right)$.

The second possibility is to offer the social security benefit only to people who identified themselves as low ability, but require them to work $R$ hours at government organized work in exchange for this benefit. Given this solution, the low-ability individuals will lower their work for wage to the level of $T-l\left(a_{L}\right)-R$, therefore, the size of the welfare benefit will rise to $Z$ $a_{L} *\left(T-l\left(a_{L}\right)-R\right)$. However, the $R$ is chosen so that $U\left(a_{H} *\left(T-l\left(a_{H}\right)\right) \geq U\left(Z,\left[\left(a_{H-}\right) T+l\left(a_{L}\right)-R\right] /\right.\right.$ $\left.a_{H}\right)$. In other words, with the work requirement, the high-ability individuals will not take this solution because working $R$ hours in the private market for a higher wage will generate more utility for them than participating in the government program. This solution to the failure of the social programs due to the behavioral response in called "workfare". The workfare expenditures of $E=N^{*} \lambda^{*}\left(Z-a_{L} *\left(T-l\left(a_{L}\right)-R\right)\right)$ will be cheaper for the government than the first solution if there is sufficient difference between the wages of high and low income groups (the difference must be such that $a_{L}<(1-\lambda) a_{H}$ ) (Besley\& Coate 1992).

Most countries finance their social security programs by payroll taxes or other taxes on wage income. The tax as the source of funding for the SSN can be introduced into the model. Under the assumptions of the model, it is reasonable to tax income of high-ability individuals only, because the social system will have to return to the low-ability individuals all the taxes that they paid. It also does not matter if the tax is a payroll tax (tax on enterprise) or income tax (tax on a person), because in any case, in a competitive labor market, the tax will result in decreased wage income of the workers.

If the government imposes the tax of $\tau$ on the income of high ability people, the wage that they receive will become $(1-\tau) a_{H}$. Given the concave utility function, the high ability people will work less and their wage income will become $(1-\tau) a_{H} *\left(T-l\left((1-\tau) a_{H}\right)\right)$. According to the model, in this case the total expenditures of the welfare system will increase. If the government is not able to observe individual's abilities, the government will have to implement a more costly system that provides benefits to everyone, but the benefit provided to the high-ability population will rise. If the government implements the "workfare" system, this task may become impossible if the tax is significantly high because the "workfare" system is only able to be implemented if the following condition holds: $a_{L}<(1-\lambda)(1-\tau) a_{H . .}$ The government will also have to increase the work requirement $\mathrm{R}_{\tau}>\mathrm{R}$, since the difference in the cost of leisure for high ability people will be lowered. 
If the welfare system is fully financed by the taxes on wages, the government faces an additional constraint in terms of our model. The total expenditures of the system can not exceed the total amount of taxes collected $E=N(1-\lambda) \tau a_{H}\left(T-l\left((1-\tau) a_{H}\right)\right)$, and the tax rate must be limited so that the condition $U(Z, R)<U\left(a_{H}\left(T-l\left((1-\tau) a_{H}\right), T-l\left((1-\tau) a_{H}\right)\right.\right.$ holds, otherwise the high-ability people will exit labor market. The highest benefit that can be offered to poor people in this case can not exceed $(1-\lambda) \tau a_{H}\left(T-l\left((1-\tau) a_{H}\right)\right) / \lambda$, and this benefit will not alter behavior of high-ability people only if the "workfare" system is used in the country.

Increased taxes or a government deficit can crowd out investment; increased payroll taxes can decrease labor demand; additional income of the poor population can increase demand for some goods and, given limited supply, cause inflation. There is a wide array of literature about the macroeconomic impact of an increase in government spending and social welfare benefits in particular. The empirical evidence in these publications suggests that the negative effect of the increase in social benefits on investment and labor supply likely outweighs its positive impact on private consumption. The literature discusses three major channels for the impact of benefits on an economy: decrease in employment, growth of the shadow economy, and the direct impact on the GDP growth, which combines all factors together. Below we discuss the empirical findings and the estimates of the size of the effect for all these channels.

\subsection{Effect on employment}

Our model assumes that every individual in the country can consume either goods $c$ or leisure l. The simplest models assume that every individual has the same concave and twice differentiable utility function $U(c, l)$ which this individual tries to maximize subject to a budget constraint $c=b+(1-\tau) * w^{*}(T-l)$. The model implies that the larger benefit $b$ received by an individual, the less he/she will work, since he/she can afford larger consumption of both goods and leisure. This effect also leads to the change in behavior for some people, who prefer to work less (or cease to work) in order to qualify for the benefit. These effects are widely observed at the individual level and they result in larger costs of welfare programs. However, the effect of the increased benefits on total labor supply is relatively small because only a small fraction of the labor force is affected.

A larger effect on the labor supply and employment is observed when the government imposes or increases taxes on wages in order to finance the social benefits. Since the tax is imposed on all workers, the effect is easier to observe at the macroeconomic level.

The microeconomic model implies that a decrease in wages as the result of the tax will have two effects: it will decrease the income of the person and stimulate him/her to work more in order to achieve their former, pre-tax consumption level; and it will decrease the "price of leisure", causing the person to consume more leisure in order to increase their level of utility. If the income effect dominates the substitution effect, the workers will work more after the increase in the tax rate. However, most empirical estimates suggest that the substitution effect likely dominates the income effect, and the elasticity of labor supply to an increase in taxes is negative. The report of the Congressional Budget Office of the USA in 1996 (1996) reviewed a number of studies and concluded that labor supply elasticity to a change in wages ranges from 0 to 0.3 for the whole population.

An increase in taxes on wages does not necessarily result in a change of the net-of-tax wage or is not fully translated into such a change. The effect of taxes on wages is better observed at 
the macroeconomic level. For macroeconomic analysis, individual labor preferences are aggregated into the labor supply function. Enterprise demand for labor is also aggregated into the labor demand function. The conventional market economy model suggests that employment and wages are set by the intersection of these two curves. A tax on workers' wages shifts the labor supply curve up and the new wage is larger than in the previous equilibrium, meaning that some portion of the tax shifted to the enterprise. If the tax is imposed on the enterprise, it shifts the labor demand curve down resulting in a lower equilibrium wage, and shifting some portion of the tax on workers.

The possibility to shift taxes on employees (in the form of reduced post-tax wages) depends on the elasticity of labor supply. Less elastic labor supply allows wages to be decreased without a significant loss in hours worked. A perfectly inelastic supply of labor allows for shifting payroll taxes to employees. Kugler (2003) and then Góra et al. (2006) argued that blue-collar (low-skilled) workers have a higher elasticity of wages than white-collar (highskilled) workers, and show empirical evidence that a payroll tax decrease(increase) causes a larger employment gain(loss) for low-paid workers than for high-paid workers. The high elasticity of labor supply of the low-paid workers in the country where this effect was studied was attributed by the authors to the relatively generous system of non-employment benefits, the large shadow economy and a binding minimum wage.

By design, social security contributions (payroll taxes) are social insurance for workers and can be viewed as savings. If workers believe in the system they have to treat their payroll taxes as part of their income (with some discount perhaps), and be indifferent between packages of higher wages and no-taxes, and lower wages with payroll taxes. In this case, any change in payroll taxes could be passed through to employees without a change in employment (Gruber 1997). However, there is little evidence of this intertemporal substitution effect (Gwartney et al 1998).

Instead, a number of studies find a significant effect of changes in payroll taxes on employment. Kugler (2003) estimated that a 10\% increase in payroll taxes resulted in a 4-5\% reduction in employment in Columbia; Gora et al. (2006) estimate that the same increase could result in a 5\% reduction of employment in Poland, and Gwartney et al. (1998) suggest that a $10 \%$ increase in the after-tax wage will result in a $3 \%$ increase in employment in the USA. From the review of results found in the literature, we can expect similar results for Russia and Ukraine.

\subsection{Effect on shadow economy}

The effect of welfare programs on the shadow economy drew a lot of attention in CIS countries (Kaufman, Kaliberda 1998) because of the large shadow economies in the countries of the region and because of the recent experience of the country. The shadow economy in Ukraine was estimated to be around $40 \%$ of the official economy in 1996 , about $20-39 \%$ in 2000 (Mel'ota et al. 2001a, 2001b) and above 50\% of GDP (41.2\% of the working age population) in 2000/2001 (Schneider, 2003), which was the highest level in Europe; in Russia in $2000 / 2001$, the share of the shadow economy in GDP was above $45 \%(40.9 \%$ of the working age population) (Schneider, 2003).

The shadow economy in a country can be influenced by the social security net in two ways. If the social security benefits, such as pensions, unemployment insurance, or health insurance, are linked to employment (for example, as in the continental social security system model), 
then the workers in shadow economy are not eligible for these benefits. If the workers trust the social security system to deliver insurance when they need it, then larger amounts of possible benefits will stimulate workers to find official employment or put pressure on enterprises to hire them officially. There is evidence (Johnson et al 1999, Belev 2003) that larger government expenditures are associated with a reduction of the shadow economy.

However, the positive effect of increased social security benefits on the reduction of the shadow economy is only observable if it is separated from the effect of increased social security contributions or other taxes that finance the SSN. Taxes are found to be one of the major causes of the existence of the unofficial economy by all studies reviewed. Large payroll taxes increase incentives for employers to pay their employees off the record. A large personal income tax stimulates employees to agree to receive payments off-the-book. If other taxes are relatively low, large taxes on labor may result in hiding full salaries, which lowers the tax base for labor taxes but does not necessarily result in a large shadow economy because all the output remains in official economy. However, if other taxes are also high, then both workers and enterprises are better off conducting part of their business in the shadow economy. In the first several years of transition, most of the CIS countries had payroll taxes of around $50 \%$, progressive personal income tax rates up to $50 \%$, and profit taxes around 30 $40 \%$. This resulted in the development of massive unofficial economies and shadow employment in these countries.

Both tax rates and the complexity of the tax system are important determinants of the size of the shadow economy. Schneider (2003) and Johnson et al. (1999) showed that the complexity of the tax system measured by the propensity of tax exemptions is a more important determinant of the size of the shadow economy than the tax rates. A similar result was described for Ukraine by U. Mel'ota et al. (2001a), who showed that the complexity of regulations, including the tax system, is the most important determinant of the shadow economy in Ukraine.

The tax burden, measured either as the tax rates or as tax revenues as a share of GDP, is the most commonly discussed cause of the shadow economy. Different studies show that an additional $1 \%$ of government tax revenues could result in a $0.3-0.9 \%$ increase in the share of the shadow economy Studies that made distinctions between different taxes found that indirect taxes are a less significant determinant of the size of shadow economy, while direct taxes on wages and profits had a significant impact on the size of the unofficial activity. In Ukraine, a combination of personal income tax and social security contributions were found to be important determinants of the size of the shadow economy before the personal income tax reform in 2004. Mel'ota et al. (2001b) estimated that if the taxes in Ukraine remained at the level of 1993-1994, the share of the shadow economy in 2000 would be about $20 \%$ higher than it was historically observed. 


\section{Tax wedge and employment - estimation of possible results of tax wedge shift for employment in Russia and Ukraine}

Let us begin with some simple theoretical considerations, explaining our research strategy. Figure 4.1 (panel (a)) presents the theoretical relationship between productivity and (net) wages. Let us assume this relationship is convex. This means that for high productivity levels, the productivity-wage elasticity is very high and it decreases as the productivity level goes down. For very low productivity levels, the wages are "rigid" - i.e. they do not react, or react insignificantly, to productivity changes.

On our schedule (Figure 4.1 panel (a)), an exogenous increase of labour costs, such as an increased tax wedge, results in a shift of the productivity-wage curve to the right. This means that the productivity of an individual has to increase in order to earn the same (net) wage, or that the wage must be reduced if productivity can not adjust. Essentially, the worker's value for the employer must increase as the exogenous costs of her/his employment go up. If the productivity-wage relationship is convex, as on our schedule, substantial wage reductions are possible only in the case of highly productive workers.

The rightward shift of the productivity-wage schedule is equivalent to the downward shift of the labour demand curve for a given productivity level as on Figure 4.1 panel (b). Rigid wages of workers with low productivity will result in large employment reductions and flexible wages of high-productivity workers will result in smaller employment reductions. This leads us to the concave productivity-employment relationship from Figure 4.1 panel (c). This explicitly illustrates the effect of a tax-wedge increase on employment for the labour force strata characterised by varying productivity levels. 
Figure 4.1 Illustration of theoretical relationship between productivity, wages and employment consequences of a tax wedge increase.

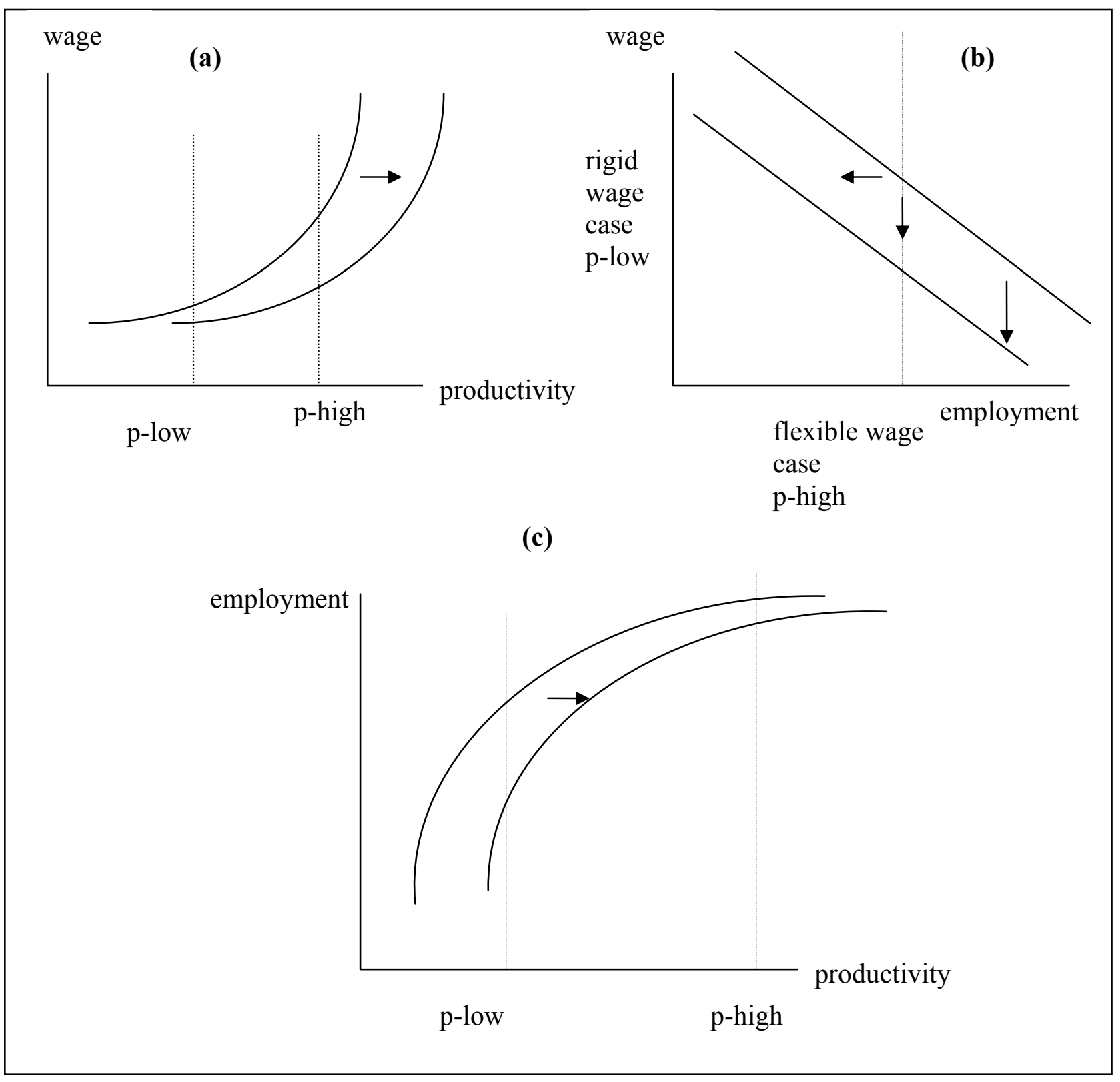

Below we try to estimate the results of such a tax wedge increase on employment depending on the productivity levels for both countries analysed. The calculations for Russia have been run on the RLMS dataset for 2005 and the calculations for Ukraine on the ULMS dataset for 2003.

We have estimated the log linear wage model for both Ukraine and Russia. The model specification in both cases included: age, age square, gender, region of residence and education level of an individual. In both cases the model has been estimated only for full-time employees. In order to exclude outliers, the observations from the lowest and highest wage percentiles have been excluded. 
The next step of our analysis was to calculate the fitted values from the model (expected wages) for the entire working age population (15-74). These would serve as the proxies for individual productivity levels. Actual employment rates have been calculated for each percentile of the expected wage distribution. A simple bivariate model has been estimated for both countries relating the employment rate for each percentile of expected wage distribution to the respective average log-expected wage. Log wage has been used as the explanatory variable in order to take into account the concavity of the expected wage (productivity) employment relationship as is clearly visible on Chart 4.1. As a result, we have obtained two functions of the employment rate to expected wage level as presented on Chart 4.1. This function mimics the theoretical relationship presented in Figure 4.1 panel (c).

Using the estimated functions one can now calibrate the expected employment effect of a proportional tax wedge change in Russia and in Ukraine for various labour force groups defined by their expected wage levels. This has been done, and the results of a $10 \%$ tax wedge cut for both countries are presented in Chart 4.2 where, for the sake of comparability, the expected wage levels on the horizontal axis have been replaced by the respective percentiles. The percentage change of employment has been placed on the vertical axis of Chart 4.2.

Chart 4.1. The actual and fitted relationship between estimated expected monthly wage and employment rates for Russia (2005) and Ukraine (2003).

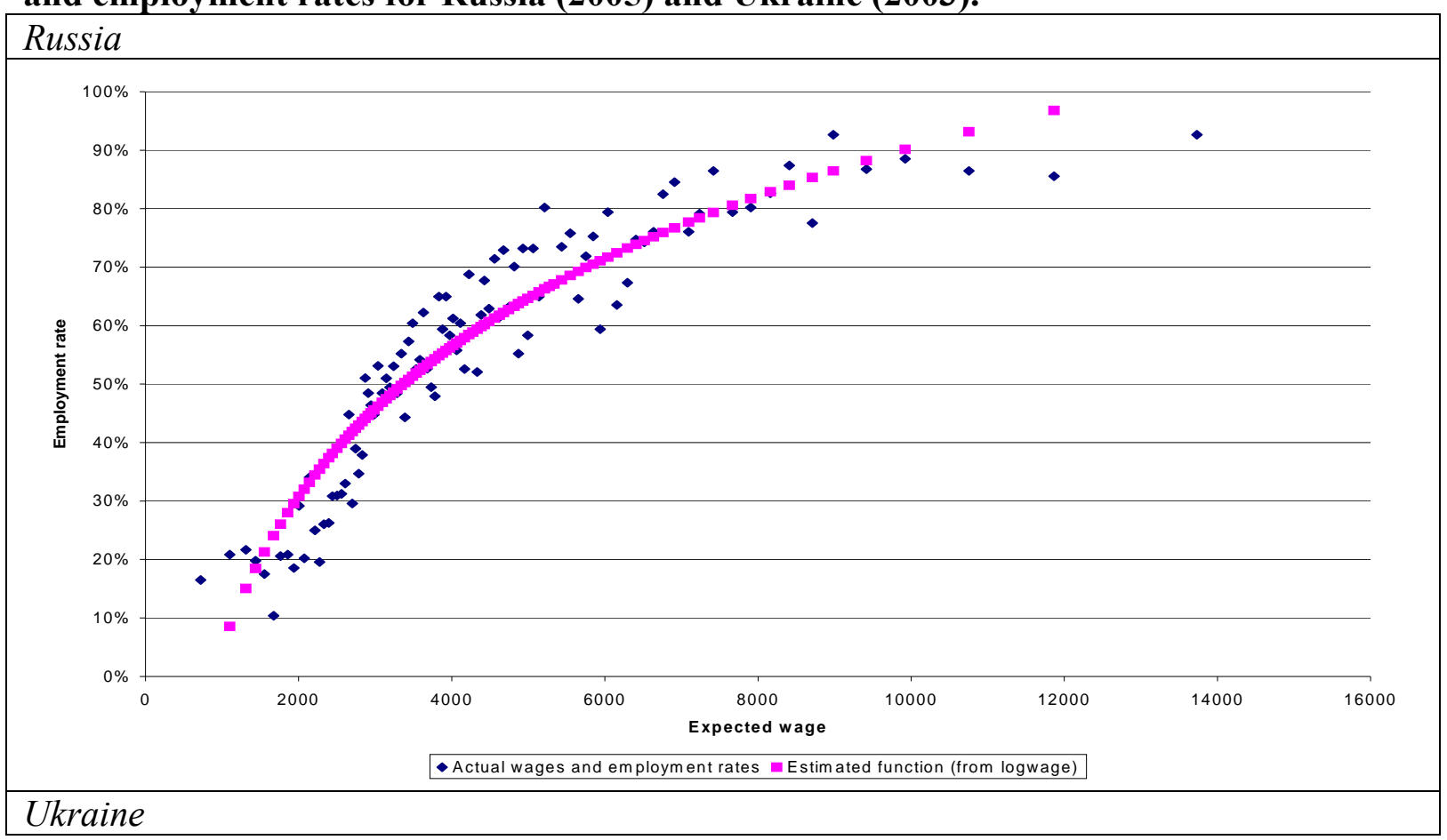




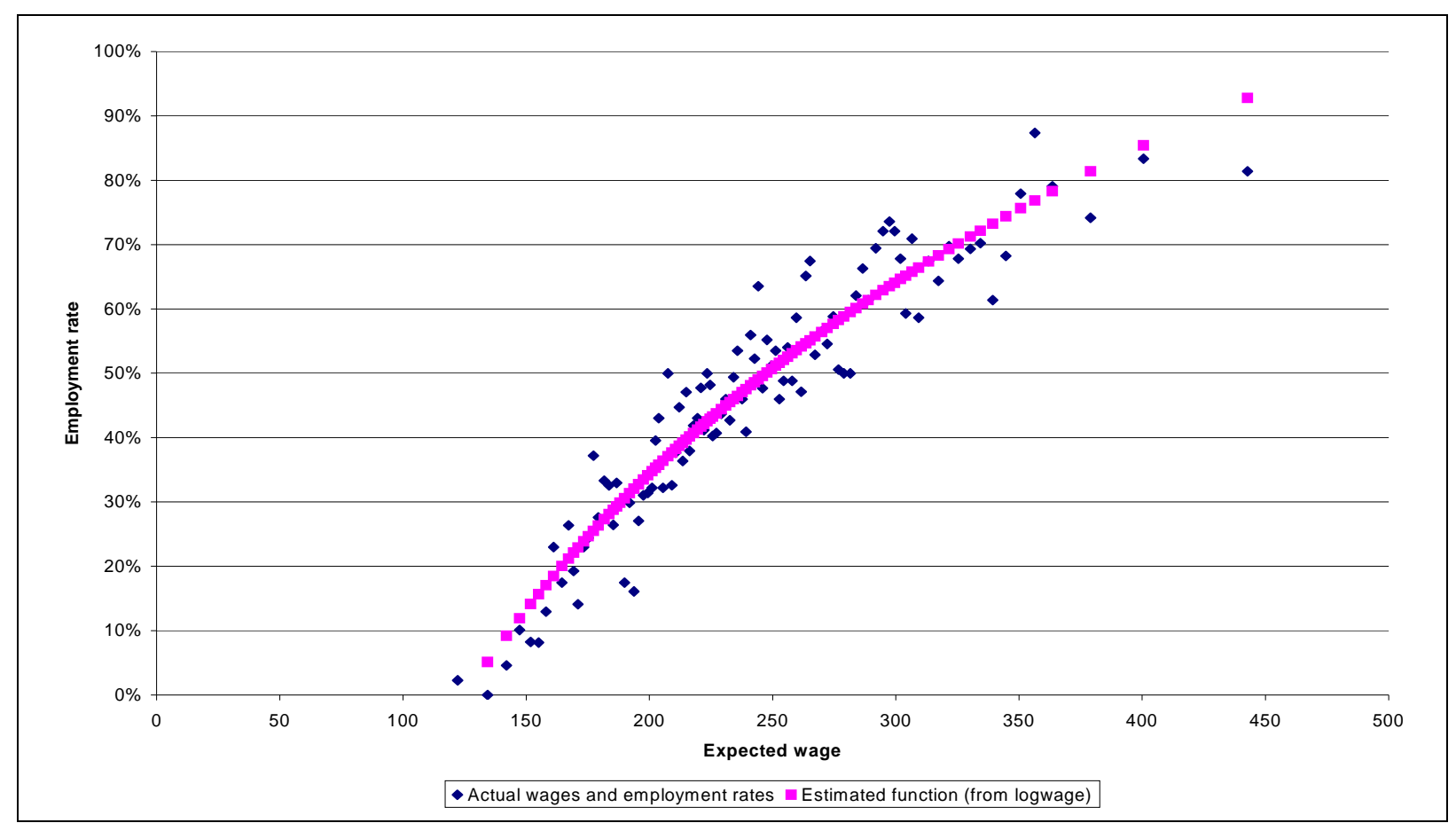

Source: Own calculations based on RLMS 2005 for Russia and ULMS 2003 for Ukraine.

Chart 4.2 The calibrated percentage changes in employment for percentiles of estimated expected wage in Russia and Ukraine.

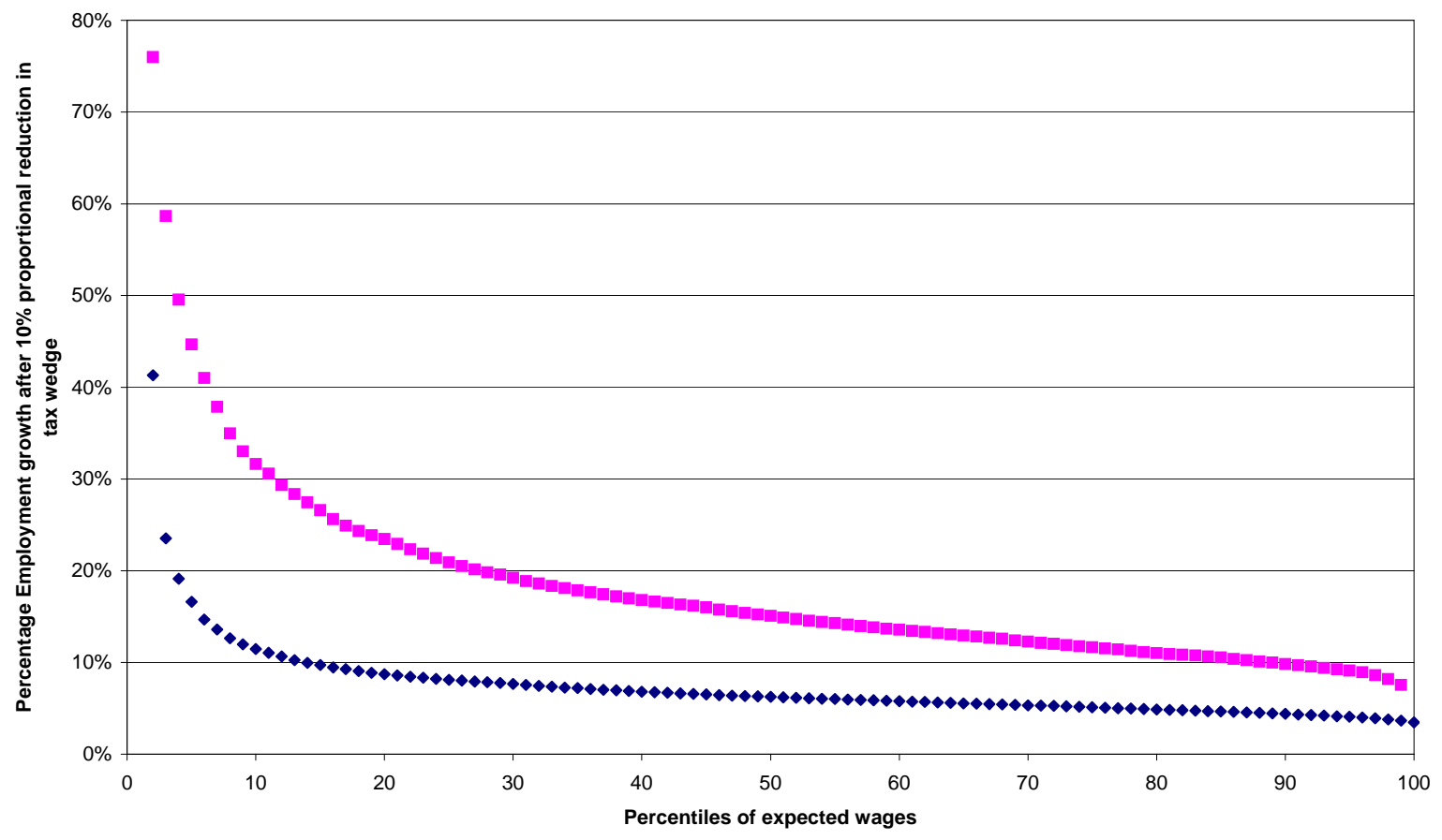

- Employment growth \% - Russia — Employment growth \% - Ukraine

Source: Own calculations based on RLMS 2005 for Russia and ULMS 2003 for Ukraine.

As one can see, the total employment effects of the tax wedge cut have been calibrated to be much higher in Ukraine than in Russia. The total employment result of the $10 \%$ tax cut increase according to our results would be 6\% employment growth in Russia and as much as $15 \%$ employment growth in Ukraine. 
There are also (and this is the most important result from our point of view) pronounced differences between the employment effects for more productive workers (with higher expected wages) and less productive workers (with lower expected wages) in both countries. The number of employed with expected wages below the median would grow in Russia by $11 \%$ and in Ukraine by $24 \%$. For those above the median, the respective changes would reach $4 \%$ in Russia and $11 \%$ in Ukraine.

The results of this simple econometric exercise are only illustrative. They should not be treated as point estimates of effects of any real processes. They shed some light, however, on possible differences between the tax wedge influence on employment levels of unproductive, unskilled workers characterised by low and rigid wages, and highly productive skilled workers with high and flexible wages. The difference in results between countries analysed is also very interesting. They obviously result from differences in the starting levels of both total and relative employment rates for various groups of the labour force in Russia and Ukraine. 


\section{Tax wedge and shadow employment - estimations for Ukraine}

The next point of our analysis is to estimate the effect of a tax wedge change on shadow employment. We tried to run such an exercise on the basis of the Ukrainian tax reform of 2005. One of the crucial points in studying shadow employment is the ability to identify shadow activities, shadow income, or the simple fact of shadow employment. Unfortunately, none of the data sources at our disposal provided the possibility to observe shadow employment directly when the tax wedge changed in Ukraine.

The ULMS has attempted to ask for shadow employment directly. The survey questionnaire contained the question, "Are you officially registered at this job, that is, on a work roster, work agreement, or contract?". Unfortunately, this question is related only to the current (or most recent) job, which for the first wave of the ULMS was 2002 or 2003 . We can observe the distribution of the low-skilled and high-skilled workers who self-reported being officially registered or not registered at their current job. However, because we do not have longitudinal data over the time period when the tax wedge changed, we are unable to make any statistical arguments about the effect of social security taxes on this distribution. Even if we had the longitudinal data, we could not capture the entire phenomenon of unofficial employment with the ULMS data. The question cited above allows capturing only fully unofficial (unregistered) employment. However, conversations with Ukrainian employees and employers suggest that, in some cases, shadow employment results from underreporting hours of work or wages rather than non-registered employment. Nevertheless, we use this information later to estimate the income effect of being employed in the shadow economy.

The UHES does not have an indicator for a person who has unofficial employment. However, it has data on personal and family expenditures and, therefore, we can try to estimate unofficial employment income as the difference between incomes and expenditures of a family. Because expenditures are reported at the level of the household, we can not determine if a specific member of the household is involved in the shadow economy. We can determine only that the household has shadow (unreported) income, if the amount of household expenditures exceeds the amount of household income. Because UHES is a special tool to study household expenditures, it has more accurate and detailed information about the expenditures than the revenues. One of the peculiarities of the survey is that it allows for the estimation of the amount of household self-production consumed by the same household. This amount is not reported by the household as a source of income. However, this amount is included in the total household expenditures. Therefore, own production of food for own household consumption is considered as "shadow income" according to our definition. Unfortunately, the dataset available for this study was a reduced version of the original UHES data. It excluded detailed information about expenditures, and contains only information about total household income. Therefore, we were unable to calculate the household expenditures without consumption of self-produced food.

In order to reduce disparities from inclusion of the production of food for personal consumption into the total expenditures, and since even without this disparity it is unlikely that income and expenditures in a given month or three-month period match exactly, we mark the household as "receiving shadow income" only if the per-capita (difference divided by 
number of members of the household) difference between expenditures and income exceeds $100 \mathrm{UAH}$ (approximately $\$ 20$ in 2005).

The UHES data reports income from the same source at both the family and individual member levels. In 1999-2002, these numbers do not always match. Because of this discrepancy, we created three possible indicators of the shadow economy: one based on the household-level income reported in UHES, another is based on the sum of individual incomes reported by the household members (plus incomes from sources that are reported only at the household level), and the third assuming that there is a shadow income if individual and household level incomes do not match. All of these are based on the simple assumption that, speaking about their individual incomes, the respondents are likely to report only their official incomes, while when reporting on total incomes or expenditures they are more likely to reveal actual income levels.

The distribution of households by education level of the head of the household (used as a proxy for skills in this case) is significantly different for families that are identified as receiving shadow income and families without shadow income. Table 5.1 presents the distribution for the shadow income defined as total income reported in the household-level data and total household expenditures. Because household-level data for 2003 available for this study contained limited information, we are unable to report this distribution for 2003. However, this problem was fixed by using individual-level income data in Table 5.2. Table 5.2 presents the distribution of families by education level of the head of household in families with and without shadow income. In this table the shadow income is identified as the difference between total household expenditures (reported in household level data) and the sum of incomes of household members (reported at the individual level in a separate dataset).

Table 5.1 Distribution of households with and without shadow income by education level of the head of household (shadow indicator: difference between sum of incomes and sum of expenditures reported at household level)

No shadow income

\begin{tabular}{|c|c|c|c|c|c|c|c|c|}
\hline & 1999 & 2000 & 2001 & 2002 & 2003 & $2004 \mathrm{q} 1$ & $2004 \mathrm{q} 4$ & 2005 \\
\hline Higher & 16.08 & 14.43 & 14.44 & 16.08 & & 19.80 & 18.30 & 20.15 \\
\hline Bachelor & 1.11 & 2.32 & 0.51 & 0.57 & & 1.11 & 1.11 & 0.64 \\
\hline Unfinished higher & 23.73 & 19.50 & 20.84 & 22.83 & & 21.23 & 20.40 & 20.90 \\
\hline High school & 31.31 & 34.19 & 34.50 & 34.10 & & 35.95 & 36.31 & 37.25 \\
\hline Middle school & 11.02 & 13.32 & 14.10 & 13.98 & & 12.88 & 13.55 & 12.61 \\
\hline Junior school & 11.78 & 11.33 & 11.23 & 9.24 & & 6.95 & 7.53 & 6.65 \\
\hline Does not have junior & 3.99 & 3.27 & 3.34 & 2.23 & & 1.44 & 1.63 & 1.32 \\
\hline Can not read & 0.90 & 1.44 & 0.76 & 0.50 & & 0.11 & 0.24 & 0.20 \\
\hline No answer & 0.08 & 0.18 & 0.28 & 0.48 & & 0.53 & 0.94 & 0.28 \\
\hline \multicolumn{9}{|c|}{ Shadow income } \\
\hline Higher & 16.02 & 16.37 & 15.35 & 5.29 & & 5.44 & 2.32 & 5.08 \\
\hline Bachelor & 1.30 & 2.36 & 1.34 & 0.00 & & 0.47 & 0.00 & 0.73 \\
\hline Unfinished higher & 23.72 & 21.19 & 22.76 & 28.37 & & 13.95 & 17.50 & 16.67 \\
\hline High school & 29.54 & 32.78 & 33.69 & 33.61 & & 40.55 & 53.46 & 53.59 \\
\hline Middle school & 11.97 & 13.23 & 14.13 & 22.43 & & 19.94 & 14.60 & 14.51 \\
\hline Junior school & 13.12 & 10.20 & 9.64 & 5.47 & & 13.96 & 6.77 & 6.77 \\
\hline Does not have junior & 3.33 & 2.93 & 2.07 & 3.16 & & 3.90 & 2.99 & 2.08 \\
\hline Can not read & 0.83 & 0.67 & 0.55 & 1.67 & & 1.26 & 0.51 & 0.00 \\
\hline No answer & 0.18 & 0.27 & 0.48 & 0.00 & & 0.51 & 1.85 & 0.57 \\
\hline
\end{tabular}


Table 5.2. Distribution of households with and without shadow income by education level of the head of household (shadow indicator: difference between sum of members' incomes and total household expenditures)

No shadow income

\begin{tabular}{|c|c|c|c|c|c|c|c|c|}
\hline & 1999 & 2000 & 2001 & 2002 & 2003 & $2004 \mathrm{q} 1$ & $2004 \mathrm{q} 4$ & 2005 \\
\hline Higher & 28.84 & 21.50 & 19.27 & 16.33 & 18.31 & 19.80 & 18.30 & 20.15 \\
\hline Bachelor & 1.21 & 4.43 & 0.54 & 0.55 & 1.05 & 1.11 & 1.11 & 0.64 \\
\hline Unfinished higher & 24.70 & 22.24 & 26.05 & 22.88 & 20.04 & 21.23 & 20.40 & 20.90 \\
\hline High school & 26.09 & 33.57 & 34.68 & 33.60 & 35.39 & 35.95 & 36.31 & 37.25 \\
\hline Middle school & 7.92 & 7.76 & 9.03 & 14.03 & 14.24 & 12.88 & 13.55 & 12.61 \\
\hline Junior school & 7.61 & 8.14 & 8.21 & 9.41 & 8.23 & 6.95 & 7.53 & 6.65 \\
\hline Does not have junior & 3.25 & 1.02 & 1.65 & 2.20 & 2.00 & 1.44 & 1.63 & 1.32 \\
\hline Can not read & 0.38 & 1.34 & 0.17 & 0.51 & 0.41 & 0.11 & 0.24 & 0.20 \\
\hline No answer & 0.00 & 0.00 & 0.40 & 0.48 & 0.32 & 0.53 & 0.94 & 0.28 \\
\hline \multicolumn{9}{|c|}{ Shadow income } \\
\hline Higher & 15.45 & 15.80 & 14.78 & 8.98 & 8.54 & 8.01 & 6.46 & 7.57 \\
\hline Bachelor & 1.28 & 2.26 & 1.20 & 0.80 & 1.60 & 0.68 & 0.94 & 0.75 \\
\hline Unfinished higher & 23.67 & 20.86 & 22.00 & 22.18 & 14.94 & 15.73 & 16.50 & 16.73 \\
\hline High school & 29.94 & 32.98 & 33.80 & 45.84 & 45.41 & 39.79 & 49.00 & 51.54 \\
\hline Middle school & 12.02 & 13.50 & 14.56 & 13.54 & 16.69 & 18.69 & 16.40 & 14.55 \\
\hline Junior school & 13.18 & 10.49 & 10.16 & 4.81 & 8.45 & 12.56 & 7.68 & 7.05 \\
\hline Does not have junior & 3.42 & 3.08 & 2.42 & 2.97 & 3.25 & 3.39 & 1.59 & 1.21 \\
\hline Can not read & 0.86 & 0.77 & 0.63 & 0.45 & 0.40 & 0.60 & 0.14 & 0.17 \\
\hline No answer & 0.17 & 0.26 & 0.43 & 0.43 & 0.72 & 0.56 & 1.28 & 0.44 \\
\hline
\end{tabular}

The results of Table 5.1Błąd! Nie można odnaleźć źródła odwołania. and Table 5.2 are similar. As we approach the most recent years, particularly 2004-2005, we observe that the proportion of households headed by high-school graduates in the group with shadow income increases, while the proportion of people with higher education significantly decreases.

One of the possible explanations for that is that new payroll taxes introduced in 2004 significantly reduced the tax wedge for salaries exceeding the "payroll tax maximum" (incomes over $2400 \mathrm{UAH}$ a month at the beginning). The reduction of the tax wedge reduced the stimulus for engaging in shadow employment. The most educated (high-skilled) people are most likely to receive high wages. It is also likely that working members of households headed by a person with higher education have similar education levels. Therefore, once the tax wedge on high wages is reduced, these people are most likely to stay out of shadow employment. The category of the most educated persons may also include people with incomplete higher education, since a university diploma is not a prerequisite of success at work, but study at a university is a potential indicator of the high abilities of the individual.

The next category, people with completed high school education, should be affected by the payroll tax maximum in the opposite direction. This category of people is sufficiently educated ("semi-skilled"); therefore, they are likely to work for wages that are higher than minimum wage. However, their wages are likely to be lower than wages of people with higher education, and are lower than the maximum taxable by payroll taxes. Therefore, paying payroll taxes on employees with complete higher education is most costly for an employer on a per-employee basis. An employer might be interested in officially registering and paying an extremely high official wage to a person with a high education, simultaneously decreasing the 
wage or number of registered employees with high school diplomas. The increase in wages for people with higher education is not taxed by the payroll tax since it is above the maximum. This increase then can be unofficially re-distributed by the employer to the nonregistered employees with high-school diplomas. The overall tax obligation of the enterprise will decrease. At the same time, it is less likely that such a tax evasion scheme will be used for low-skilled (with education below high school) employees. These employees are working at wages close to the minimum wage and the gain from unofficially employing such people is smaller, while the risk for the employer of being caught by tax inspection remains the same.

In order to investigate this hypothesis, we combined our household-level UHES data into a single file and ran a simple regression to determine if a reduction of the tax wage has an impact on the probability of participating in the shadow economy. Combining the UHES datasets for different years does not produce panel data similar to that of a longitudinal survey because we have only one observation per household and treat every observation individually. This reduces our ability to estimate the size of the effect that a tax wedge has on the probability to have shadow income. However, it allows us to determine the statistical significance of a difference in the tax wedge, explaining the probabilities of having shadow income before and after reform.

We ran a simple PROBIT regression in reduced form for the probability of having shadow income. The aim of this analysis was to reveal the influence of tax reform on the probability of having shadow income, depending on the education level of the household head. The lefthand-side variable is equal to one if the difference between per-capita household expenditures and per-capita household income (determined as the sum of personal incomes of all members of a household) is higher than $100 \mathrm{UAH}$ a month. The right-hand-side (explanatory) variables consist of a dummy for the payroll tax reform (equal to one in 2004-2005, and zero otherwise), dummies for the level of education of the head of household and the multiplicative variable combining the reform dummy and education dummy. We added dummies for years and for geographical locations in order to capture at least some fixed effects and increase the quality of the estimate for the effect of the payroll tax reform dummy (not reported in Table $5.3)$.

Table 5.3. Results of PROBIT regression, probability of household to have shadow income for various education levels

\begin{tabular}{|c|c|c|c|c|c|c|}
\hline \multirow{3}{*}{$\begin{array}{l}\text { Number of obs } \\
\text { Log likelihood }\end{array}$} & \multirow{3}{*}{$\begin{array}{l}= \\
=\end{array}$} & 78192 & \multicolumn{2}{|l|}{ LRchi2(47) } & $=$ & 54001.830 \\
\hline & & -27136.2 & Prob $>$ chi2 & & $=$ & 0.000 \\
\hline & & & Pseudo R2 & & $=$ & 0.499 \\
\hline Variable & Coefficient & Std. Err. & $\mathrm{z}$ & $\mathrm{P}>|\mathrm{z}|$ & $\begin{array}{l}95 \% \\
\text { Conf }\end{array}$ & Interval] \\
\hline Payroll tax reduction & -2.55368 & 0.03253 & -78.51 & 0.000 & -2.61743 & -2.48993 \\
\hline \multicolumn{7}{|c|}{ Multiplicative tax reform $\mathrm{X}$ education level dummies } \\
\hline Higher & -0.49091 & 0.03863 & -12.71 & 0.000 & -0.56663 & -0.41520 \\
\hline Bachelor & -0.29594 & 0.12674 & -2.34 & 0.020 & -0.54435 & -0.04753 \\
\hline Unfinished higher education & -0.19395 & 0.03397 & -5.71 & 0.000 & -0.26053 & -0.12737 \\
\hline Middle school & -0.01626 & 0.03717 & -0.44 & 0.662 & -0.08911 & 0.05659 \\
\hline Junior school & 0.09246 & 0.04305 & 2.15 & 0.032 & 0.00809 & 0.17684 \\
\hline \multicolumn{7}{|c|}{ Education levels } \\
\hline Higher & -0.15456 & 0.02863 & -5.40 & 0.000 & -0.21068 & -0.09844 \\
\hline Bachelor & 0.08658 & 0.08837 & 0.98 & 0.327 & -0.08662 & 0.25978 \\
\hline Unfinished higher education & -0.05849 & 0.02602 & -2.25 & 0.025 & -0.10949 & -0.00749 \\
\hline
\end{tabular}




\begin{tabular}{|l|l|l|l|l|l|l|} 
Middle school & -0.08163 & 0.02930 & -2.79 & 0.005 & -0.13905 & -0.02421 \\
\hline Junior school & -0.28883 & 0.03270 & -8.83 & 0.000 & -0.35293 & -0.22473 \\
\hline
\end{tabular}

Source: Own calculations based on UHES data for years 2000-2005. High school is the base category for education levels.

The results of the regression seem to partially support our hypothesis of a much stronger effect of the most recent tax reforms on the probability of having shadow income in the case of households headed by a person with finished higher education. The coefficient for the reform period, as such, is negative and significant, indicating the overall expected negative influence of tax reform for the probability of having shadow income. The coefficients on the multiplicative dummies indicate that the result of the reform was much stronger for those with at least unfinished higher education. It seems, therefore, that the most recent tax reform in Ukraine could lead to an overall reduction of shadow employment. It proves implicitly that there exists a significant interdependence between tax wedge levels and shadow employment, this being the most important result from the point of view of our analysis. On the other hand, our findings indicate that the reform was not able to target those groups who are expected to engage in the shadow economy most often, i.e. low-skilled persons. 


\section{Shadow employment, wages and access to social security in Ukraine and Russia}

\subsection{Some assessments of the size of the informal employment}

According to existing evidence, the current scale of informal employment in Russia is significant, albeit not as high as e.g. in less developed countries. The combined share of nonagricultural, informal employment among the urban population is about $14 \%-16 \%$. About two-thirds of the urban, non-agricultural, informal workers are not actually unregistered; they do work legally but a significant part of their wage is paid off-the-record, by so-called "envelope payments". At the same time, persons working in enterprises of the formal sector account for over half of the total informal employment headcount (Sinavskaya 2005).

Migration to informal employment is clearly stimulated by an excessive level of taxation. According to the results of the survey of 1,000 SMEs in five Russian regions performed by the National Institute of Systemic Studies of Entrepreneurship in 2002, small businesses during 1999 - 2002 had not officially registered up to $30 \%$ of their payroll. Informal interviews with business infrastructure representatives have shown that unofficial cash payments amounted to $30 \%-60 \%$ of the total SME payrolls (note that the lower limit of these estimates coincides with SMEs' self-assessment). The survey results confirmed that the UST level is the major reason behind 'migration to shadow'. (Liberal Hosting 2000) Moreover, the larger the proportion of labor costs in production cost, the higher the share of the shadow employment in SMEs, since high current rates of social insurance contributions induce small businesses to understate their official wage figures.

The ILO bureau in Moscow reported that in the late 1990s, even in officially registered enterprises, actual wage figures were substantially higher compared to those fixed in labor contracts, with differences varying from two to twenty times. Informal cash payments are largely a result of a flight from high social payroll taxes. According to minimal estimates, $12 \%$ to $15 \%$ of the employees' working time is actually 'in the shadow', which enables employers to increase their wages by $13 \%$ on average. (Kosals 1999) Overall, the informal sector is responsible for generating from 25\% (Rosstat estimate) to 50\% (Ministry of Internal Affairs estimate) of the total wage bill. That is the reason why Rosstat publishes two estimates of the households' income structure: one figure corrected for the hidden payroll fund, and another one without such a correction. If we analyse the corrected income structure, we find out that the proportion of wages in total incomes increases almost twice as compared to the uncorrected one.

According to more recent data, the reduction of the UST rate has not turned the trend towards informal employment growth and has not noticeably affected the scope of shadow cash payments. (Development Centre 2006) The survey performed by Rosstat in February 2006 has demonstrated that informal employment in Russia continued to increase. In 2005, the number of employed in the informal sector of the Russian economy increased by 0.1 million people to a total of 11.6 million, or $17 \%$ of the total number of employed. Importantly, the number of employed exclusively in the informal sector has grown by 0.3 million, while the number of those who combined formal and informal employment has decreased. Hence, 
despite the reduction of informal employment growth rates in 2005, it has still accounted for about a half of the total employment growth. This means that the reduction of the UST rate in 2005 was not radical enough to induce the legalisation of labor relations.

The growth of informal employment in 2005 has affected the majority of economic sectors. In industry and construction, it was accompanied by a continuing reduction of the official employment at large and medium-sized enterprises. This is most probably due to the fact that in the situation of the growing demand for labor, its use is still being 'optimized' by transferring it into the informal sphere.

A noticeable reduction of informal employment in transportation and agriculture could hardly be attributed to employment legalization since it was accompanied by a decline in official employment as well, which is indicative of a general reduction of demand for labor in these sectors. It is only in the retail trade that the growth of official employment comparable in scale to a reduction of its informal component could indicate the flow of employment into organised forms. The reason behind this is that small retail outlets traditionally practicing "grey" turnover and informal employment are being driven out by large retail networks. The latter, especially those with foreign capital participation, as a rule tend to comply with existing legislation, including employment regulations.

The available data on Ukraine is not so detailed, although accessible information demonstrates largely similar results. The Institute of Competitive Society performed several surveys of focus groups in order to identify entrepreneurs' expectations regarding the STS reform. Seven focus groups were organized in Khmelnitsky, Belaya Tserkov, Dneprodzerzhinsk, Lutsk, Chernovtsy, and two focus groups in Kiev containing representatives from all over Ukraine. The surveys have identified the following trends regarding employment:

- registration of employees as entrepreneurs and replacement of labor relations by economic ones;

- retention of the number of employees accompanied by a formal reduction of working hours paid for officially (use of unofficial 'envelope' cash payments);

- a real reduction of the number of workers (accompanied by production decline);

- a reduction of the number of officially employed workers and use of informal employment with illegal payments.

As could be seen, any of the employment options induces a concealment of labor relations, with the third option (legal behavior) leading to a reduction of entrepreneurial activities.

Available data indicate that the informal economy is common in Ukraine as well. However, it is more often related to episodic or short-term activities, unofficial activities in the household sector, and self-employment activities, for example, which are more oriented towards survival (last resort providing subsistence income). Most likely, this is one of the substantial differences between informal employment in Ukraine versus in Russia.

Ukraine presents a lot of opportunities for informal activities and unregistered employment, often incidental and very short-term. According to information provided by Mel'ota and Gregory (2001a), unofficial activities in the Ukrainian household sector are estimated at $16 \%$ of official GDP and are a major source of the shadow economy in the country. In the situation of a relatively low demand for labor and due to the very small size of unemployment benefits, 
many people undertake various self-employment activities in order to survive; other people leave the official labor market, preferring to engage in informal activities or at a household plot; others are leaving the labor market completely, seeking additional income sources such as a stipend, pension, child care allowance, etc. Many unemployed are occasionally involved in unofficial labor or entrepreneurial activities which, to some extent, provide a means of subsistence. The most popular types of incidental unregistered activities in Ukraine include transportation services, construction and repair works, tutoring and writing of control tests and term papers, tailor services and handicrafts, welding services and car repair, low-skilled agricultural labor for private households and other personal services.

One of the explanations of existing differences between Ukraine and Russia in terms of informal employment could be different levels of minimum wages. As distinct from Russia, where this level is extremely low (less than $10 \%$ of the average wage), in Ukraine it has been increased to $44 \%$ of the average wage in 2002 . This has clearly served as an incentive for entrepreneurs to legalize wages, as well as implied that the minimum wage has regained its role as a tool for limiting wage inequalities and protecting wages of workers with weak bargaining power (Rutkowski 2006).

Payroll taxes in Ukraine are likely to both dampen labor demand by raising labor costs (particularly given the relatively high minimum wage which limits the scope for passing the tax to labor) and to reduce labor supply by reducing the take-home pay. Moreover, they are most probably an important factor behind the growth in the informal sector (Ukraine Jobs Study 2005).

On the whole, as concerns illegal hiring of the labor force, the authors of the cited report on Russia stress that factors affecting the probability of migrating into shadow employment are not yet adequately studied due to the limited representation of this workers' group in sampling surveys (Sinavskaya 2005).

\subsection{Informal employment and wages}

The next step of our analysis was to assess the results of being employed in the shadow economy for wages and access to social services provided by companies and public social security. We have estimated the net incomes model in which shadow employment has been used as one of the explanatory variables. Similar models have been estimated for Russia using RLMS data for 2005 and for Ukraine using ULMS data for 2003. In both cases we have run simple OLS regressions with the log of income from the main job used as the dependent variable. The set of explanatory variables, apart from the dummy for unregistered activity, included: age, gender, education, tenure, working hours, code of economic activity of the enterprise and regional dummies.

As we have already mentioned, using the direct responses to the question about current job of the respondent being registered or not either in RLMS or in ULMS does not result in full coverage of shadow employment in either case. We are able to identify only those performing fully unregistered jobs and not those employed legally for minimum wage or for a wage close to the minimum and receiving the rest of their remuneration in the form of additional, unregistered cash payments - "envelope payments". Hence, any results we describe below in this section relate to this specific kind of "clear" shadow employment. 
The results of our analysis indicate a negative, but only a marginally significant negative, influence of the shadow employment on net incomes from the main job, as the coefficients of the shadow employment variable are significant only at 5\% confidence level in both countries.

Table 6.1 Influence of shadow employment on net incomes from main job in Russia and Ukraine. Results of econometric estimations.

\begin{tabular}{|l|l|l|l|}
\hline \multicolumn{2}{|c|}{ Russia } & \multicolumn{2}{c|}{ Ukraine } \\
\hline Education & & Education & \\
\hline Secondary vocational & -0.33 & Tertiary-Vocational & -0.26 \\
\hline Vocational & -0.47 & Secondary general & -0.36 \\
\hline Below vocational & -0.48 & Vocational & -0.37 \\
\hline & & Below vocational & -0.43 \\
\hline Female & -0.34 & Female & -0.28 \\
\hline age & -0.005 & Age & -0.005 \\
\hline tenure & 0.008 & Tenure & 0.005 \\
\hline Hours worked & 0.007 & & - \\
\hline Shadow Employment & $-0.12 *$ & Shadow Employment & $-0.08 *$ \\
\hline Observations & 4356 & Observations & 3357 \\
\hline R-squared & 0.36 & R-squared & 0.31 \\
\hline
\end{tabular}

* - Significant at 5\% confidence level only.

In the case of Russia, work in shadow employment decreases the net wage by about $12 \%$ and in Ukraine by $8 \%$. This means that working in the shadow economy should not be treated as a way to increase wages. Those taking unregistered jobs must accept lower wages. It suggests that shadow employment in these countries is primarily a way to escape unemployment and poverty and not a way of simple tax evasion.

One must take into account, however, that our results concern only those whose jobs are not registered at all. In the case of those employed legally and receiving part of their wage offthe-record, the motivation of income enhancement is an obvious one.

\subsection{Impact of being informally employed on access to social security benefits and EPL}

Both theory and common sense suggest that unregistered employment is an unequivocally negative phenomenon for an employee because of a lack of guarantees, formal rights, grounds for court proceedings, etc. However, among 279 respondents from Moscow, Novosibirsk, Perm and Nadym engaged in unregistered (without a written contract) employment, 19\% responded that "it is profitable for myself, employer has nothing to do with it", and $42 \%$ considered the situation as profitable for both employer and employee (NISP 2003). 
All categories of workers think that losses from EPL non-compliance outweigh the respective gains. However, those in an admittedly illegal situation (employed without a written contract) regard this balance of gains and losses more optimistically. For instance, the opinion that EPL non-compliance brings more losses than gains to workers, and they tolerate it only because they are unable to change the situation, is characteristic for public sector employees $(75 \%)$ and industrial workers (64\%). At the same time, this opinion is shared by only $43 \%$ of those employed without a written contract and by $44 \%$ of SME workers, whereas EPL noncompliance is widespread.

Research on Russia based on RLMS indicates that there are "enclaves" where labor rights of workers in the informal sector are protected even to a greater extent than in the formal one. (Sinavskaya 2005) RLMS data indicate that wage arrears and forced administrative leave are more widespread in enterprises of the formal sector. According to a Moscow Carnegie Center survey, $86 \%$ of respondents with primary, nonagricultural, informal employment replied that their wages are paid in due time and only $7 \%$ mentioned wage arrears, while for respondents employed formally, these proportions constitute $78 \%$ and $23 \%$ respectively. According to RLMS data, $18 \%$ of respondents with primary informal employment and $23 \%$ of those employed officially mentioned wage arrears. Thus, apart from higher remuneration, informal employment generally ensures more stable current income, but is accompanied by a lack of social guarantees and a higher level of instability.

The majority of workers cannot see any difference between formal ('white') and informal ('black') wages. Since the size of most government guarantees (minimum wage, unemployment benefits, pensions) is miserable, and they are not 'insured' against various 'contingencies' (lack of indexation mechanism, no guarantees of payments regularity), many workers prefer to agree to informal cash payments, not thinking about contributions to the funds that they would "probably" need later in their lives. The situation of widespread EPL non-compliance to some extent equalizes the positions of the formally and informally employed from the viewpoint of their labor rights protection. The situation of social protection of workers also looks similar (Barsukova 2003).

On the other hand, in both countries, the status of being formally employed provides access to a number of benefits financed through the system of obligatory government social insurance labor pensions, unemployment benefits, temporary disability benefits, benefits to compensate the costs related to childbirths and funerals, and industrial accident benefits.

In Russia, informal employment deprives employees of the right for labor pension insurance. However, in practice, individual motivation to comply is rather weak. Individuals do not expect to get any return on paid taxes, for example, in the form of public good provision or social security provision from the present unreformed PAYG system.

This is primarily connected with very low pension benefits: the ratio of average pensions to average wages (pension replacement ratio) is about $23 \%$ and tends to fall further; in addition, an average pension represents only $96 \%$ of a subsistence minimum. As a result, incentives to contribute to the tax system are low. Moreover, unregistered workers mostly belong to the younger generation who are not really thinking about future pensions, while those closer to retirement age try to locate themselves within the formal sector. 
The World Bank studies on Ukraine indicate a similar picture. Currently, the link between social insurance contributions and pension benefits is weak and almost nonexistent, lowering the incentives for individuals to comply. Despite some changes made in the legislation and the benefit formula, the benefits are currently almost flat. Thus, the only significant link between payments and benefits is to be a participant in the system and, consequently, to receive a pension payment, almost regardless of the amount contributed. Clearly, this does not create an incentive for contributors to report their "real" income to the system, particularly contributors in the mid-range and higher income brackets (Public Finance Review 2006).

In Ukraine, the increase in the minimum pension currently occurs automatically up to the level of the "subsistence minimum." The subsistence minimum is a national amount set by the government each year in the annual budget. This link between the "subsistence minimum" and pension insurance blurs the distinction between social insurance and poverty-targeted social assistance, confuses the pension dialogue, and leads to wasteful transfers which poorly target poverty. More importantly, from the viewpoint of the current study, the difference in accessibility of pension benefits between the "legally" and "illegally" employed becomes blurred.

In Ukraine, the overall construction of the law "On obligatory state social insurance in case of unemployment" does not stimulate participation in the system and the payment of contributions. Moreover, the fact that the respective security benefits are missing is often of minor importance.

Social benefits for the unemployed in Ukraine are also, on average, extremely low and cannot be regarded as a significant factor affecting the duration of unemployment. (Kupets 2005) Their size, although related to the number of years for which social security payments were paid, is in general rather low (58\% of the minimum wage and $26 \%$ of an average wage in 2003). In addition, the number of years of security payments adds very little to the overall unemployment benefit. In fact, only a small proportion of those unemployed rely on benefits as a means of subsistence. As regards sickness benefits, their size varies from 60 to $100 \%$ of an average employee wage depending on the continuity of employment. It is only after eight years of continuous employment that a worker becomes entitled to be paid $100 \%$ of its wage as a temporary disability benefit.

Similarly, in Russia, the impact of being informally employed on access to social security and social protection schemes is of rather marginal importance.

For Russian SMEs or other firms using STS or imputed income tax, the size of temporary disability benefits is determined by the Federal Law No. 190-FZ of December $31^{\text {st }} 2002$ "On the provision of social security benefits to citizens employed by organizations or by individual entrepreneurs using special taxation regimes". According to the law, temporary disability benefits are paid from two sources:

- the Federal Social Security Fund refunds, to the employer, a part of his expenses related to the payment of a temporary disability benefit to a sick employee, not exceeding one minimum wage (MROT) per month;

- from the enterprise's own funds as regards amounts exceeding one minimum, wage.

In other words, firms using STS could obtain directly from the Social Security Fund only RUR 1,100 (or somewhat more where regional coefficients are applied) for a full calendar 
month. The remaining part would have to be paid by the entrepreneur from his own funds. This refers both to sickness benefits (including those related to industrial accidents or workrelated disease) and maternity benefits.

Importantly, even when employer funds are used for paying sickness benefits, their maximum size is limited in all taxation systems. For example, in 2006, the threshold for monthly temporary disability payments was set at RUR 15,000 (about 120\% of the average wage across Russia, but just $78 \%$ of the average wage in Moscow). The existence of such legal limitations in access to sickness benefits further contributes to a relative equalization of access to these benefits between the formally and informally employed.

According to RLMS data, more than $90 \%$ of the officially employed replied that they had an opportunity to draw on such social guarantees as a sickness benefit and maternity benefit. The Moscow Carnegie Center survey demonstrated that $89 \%$ of formally employed had an opportunity to use their right to draw on temporary disability benefits. Among the informally employed, the proportion of workers enjoying similar rights is, naturally, considerably lower. (Sinavskaya 2005)

Other social guarantees (coverage of medical insurance, education, lodging, transportation, etc.) are offered to a substantially fewer number of workers - both formally and informally employed.

The very definition of informal employment chosen for the current analysis assumes that the absence of registration of labor relations should lead to the exclusion of the informally employed from the domain of social and employment protection legislation. Hence, limited access of the informally employed to social guarantees is not surprising. More surprising is the fact that informal workers have mentioned these guarantees at all as their rights connected with current employment. For example, according to RLMS, the right for an annual paid vacation was mentioned by $93 \%$ of contractually employed and by $15 \%$ of those who were employed without a written contract. Even more surprising are the results of the Moscow Carnegie Center survey, according to which $40 \%$ of the informally employed enjoyed the right for an annual paid leave, but only $21 \%$ have made use of such an opportunity.

Having discovered this, we have tried to run an econometric exercise in order to assess the access of those informally employed to some social services provided by employers as compared to those formally employed. We have run a similar model similar for wages and access to social services as has been defined as the number of services such as (paid leave, access to preschool, sickness leave, paid holidays etc.) an employee is entitled to in her/his main job. Once again, RLMS data for 2005 and ULMS data for 2003 were used for the calculations.

Our results indicate that engaging in shadow employment limits the access to social services of the employed in both countries. The respective significant coefficients are $-2,34$ in Russia (with the average number of services available of 3.6 and the maximum number of 11) and 1,12 in Ukraine (with average number of services available of 3.2 and the maximum number of 13). The interpretation of these coefficients is straightforward - as the expected number of services lost by those in shadow employment. It would mean that Ukrainian shadow employees loose much less of their rights in the case of shadow employment than their Russian counterparts. 


\section{Conclusions}

In recent years both countries undertook serious steps in order to reform their payroll tax system. The reduction of shadow employment was one of the main objectives declared by both reforms. On the other hand, however, the main result of both reforms was to simplify the tax system from the point of view of entrepreneurs and lower taxes paid by this category of the labor force. Taxes paid by employees, especially by those with lower wages, did not change significantly. It seems that both reforms were partially successful in encouraging some entrepreneurs to disclose their activities. The Ukrainian reform could also lead to partial success in legalizing wages of workers earning higher wages. It seems, however, that it did not affect the behavior of low-wage workers in the shadow economy and, in some specific cases, the effect could even be perverse.

Our results indicate a serious reduction of the size of the tax wedge for less-skilled (lowwage) workers could have significant effects on employment levels of this group. It seems also that it could limit the size of the shadow economy; however, our results do not show this explicitly. We show that unskilled persons engaged in unregistered jobs in Ukraine and Russia are not "rewarded" with higher net earnings. It seems that, in their case, shadow employment is the way to escape unemployment and resulting poverty, rather than to evade taxes. Hence, it seems that, in this case, broadening of general employment opportunities for this group would result in a decrease in shadow employment.

These results also indicate that there is no immediate effect of the expansion of the tax base for social contributions and personal income taxes. We observe some growth in the number of jobs and amount of wages at both ends of the wage distribution. However, the governments implementing the tax cuts should not expect compensating growth of the tax base for at least two years (probably more, but our study was able to observe effects of change in tax rates only in the short-term due to the lack of data).

Being employed illegally limits access to a series of social benefits and services, particularly those provided by legal employers. On the other hand, however, the size of benefits and quality of services is very low and it is not enough to encourage those employed in the shadow economy to legalize their work. Additionally, part of the existing benefits and services are also accessible for those engaged in shadow employment, due to their general coverage, creating a free rider problem. Better targeting of social benefits and services, resulting in quality improvement and limiting free riding, could reduce the incentive to go into the shadow economy.

The size of the benefits is not the only factor determining its effect on shadow employment. In this work, we compared two countries, Russia in Ukraine. In recent years, Russia (and the Russian budget) significantly benefited from favorable conditions on the world oil market, while Ukraine experienced negative effects of the increased energy prices. This difference allowed Russia to maintain higher social benefits compared to Ukraine. However, we found that effect of the SSN benefits on shadow employment was low in both countries. One of the explanations, discussed in the paper, is the fact that current SSN benefits remain largely universal, and are not sufficiently tied to former employment history and size of SSN contributions (or, in other words, most SSN recipients belong to the group who were at the 
low wage level and their SSN benefits are not significantly different from the benefit levels of people who were officially unemployed). 


\section{References:}

Ackland, R., Falkingham, J. (1997): "A Profile of Poverty in Kyrgyzstan" in Household Welfare in Central Asia, ed. by F. J. e. al. Basingstoke: Macmillan Press

Belev, B. (2003): The Informal Economy in the EU Accession Countries: Size, Scope, Trends and Challenges to the Process of EU Enlargement. Center for the Study of Democracy, http://www.csd.bg/publications/infeconseeaccession/PART01.pdf

Besley, T., Coate, S. (1992): "Workfare Versus Welfare: Incentive Arguments for Work Requirements in Poverty Alleviation Programs," American Economic Review, Vol. 82:1, 249-26

Barsukova (2003) Теневая занятость: проблемы легализации // Проблемы прогнозирования. 2003. № 1. C. 136-147. (Shadow Economy: legalization Problems)

Buitano, M. (2000): "Note on Poverty in Ukraine", CAS Background Notes, World Bank, http://wbln0018.worldbank.org/ECA/ECC11/UkraineCAS/AR/DocLib.nsf/0/.

CBO (1996): "Labor Supply and Taxes", C. B. office

Development Centre (2006) 2ЦЕНТР РАЗВИТИЯ. ОБОЗРЕНИЕ РОССИЙСКОЙ

ЭКОНОМИКИ (за период с 6 по 19 июня 2006 г.) http://www.vedi.ru/macro_r/macro3406_r.doc (Russian Economy outlook)

CSR (2000): "Osnovnye Napravleniya Sotsial'no-Ekonomicheskoi Politiki Pravitel'stva Rossiiskoi Federatsii Na Dolgosrochnuyu Perspektivu ", Center of Strategic Research, http://www.csr.ru/about-publications/plan2010.html

Fox, L. (2003): "Safety Nets in Transition Economies: A Primer ", The World Bank Social Protection Discussion Paper Series, World Bank

Góra, M., Radziwiłł, A., Sowa, A., and Walewski, M. (2006): "Tax Wedge and Skills: Case of Poland in International Perspective", CASE Reports \#64/2006, CASE, www.case.com.pl

Gruber, J. (1997): "The Incidence of Payroll Taxation: Evidence from Chile," Journal of Labour Economics, Vol. 15:3

Gwartney, J., Lawson,R. and Holcombe, R.G., (1998): "The Size and Functions of Government and Economic Growth", Report to US Joint Economic Committee

ICS (2004) Материал подготовлен Институтом конкурентного общества, www.ics.org.ua (газета "Частный предприниматель", № 11, июнь 2004 г.) (Material of Institute of Competitive Society from journal „Private entrepreneur” No. 11, June 2004)

ILO (2001) Из доклада: Предложения к стратегии содействия сокращения бедности в России: анализ и рекомендации. М.: Московское Бюро МОТ, 2001.

(http://195.16.46.2/publications/files/REP RUSEdit.pdf) (From lecture: Proposition on how to reduce poverty in Russia")

Johnson, S. H., Kaufmann, D. and Zoido, P., (1999): "Corruption, Public Finances, and the Unofficial Economy", Policy Research Working Paper No. 2169, World Bank, $\underline{\text { http://ssrn.com/abstract }=192569}$

Kaufmann, D., Kaliberda, A. (1997): "Integrating the Unofficial Economy into the Dynamics of 
Post-Socialist Economies: A Framework of Analysis and Evidence", Policy Research Working Paper No. 1691, World Bank, http://ssrn.com/abstract=620508

Kosals (1999) Л. Косалс. Между хаосом и социальным порядком. Теневая экономика. - Pro et Contra, T. 4. №1, c.41. (Between chaos and social order. Shadow Economy).

Kupets (2001) О.В. Купец Определяющие факторы продолжительности безработицы в Украине Консорциум экономических исследований и образования "Научные доклады" № 05/01 (Selected factors influencing unemployment in Ukraine")

Kugler, A., Kugler, M. (2003): "The Labor Market Effects of Payroll Taxes in a Middle-Income Country: Evidence from Columbia", Discussion paper No. 852, IZA

Lindert, K. (2005): "Implementing Means-Tested Welfare Systems in the United States", Discussion paper, World Bank

Libanova, E. (2001): "Bednost' V Ukraine: Diagnoz Postavlen — Budem Lechit'?" Zerkalo nedeli, Vol. 337, http://www.zerkalo-nedeli.com/ie/archiv/337/.

Liberal Hosting (2000) «Коммерческий пролетариат» или малое предпринимательство?

Горизонты россий-ского малого бизнеса $\mathrm{http}$ ://iberal-1.hosting.parking.ru/sitan.asp?Num=403 Налоговые проблемы глазами субъектов малого предпринимательства (“Market Proletariat” or small business? Horizons of Russian small business")

Mel'ota, I., Gregory, P. (2001): "New Insights into Ukrainian Shadow Economy: Has It Already Been Counted?" Institute for Economic Research and Policy Consulting, http://www.ier.kiev.ua/

Mel'ota, I., Tiessen,U., Vakhnenko, T. (2001): "Fiscal and Regulatory Causes of Shadow Economies in Transition Countries: Case of Ukraine", Institute for Economic Research and Policy Consulting, http://www.ier.kiev.ua/

Milanovic, B. (1997): Income, Inequality, and Poverty During the Transition from Planned to Market Economy. World Bank

Nesporova, A. (2002): "Unemployment in the Transition Economies," Economic Survey of Europe, Vol. 2

NISP (2003) Project «Illegal labor practices and social transformations in Russia». См. Барсукова С.Ю. Теневая занятость: проблемы легализации//Проблемы прогнозирования. 2003. № 1. С. 136-147.

Ovcharova, L. (2002): "Bednost' V Stranakh S Perekhodnoi Ekonomikoi", Regional conference "Sotsial'naya politika realii XXI veka: regional'nyi aspekt", Barnaul

Public Finance Review (2006) Report No. 36671 - UA Ukraine Creating Fiscal Space for Growth: A Public Finance Review. September 14, 2006, p. 26. (World Bank)

Rutkowski J. (2006) . Labor Market Developments During Economic Transition. World Bank Policy Research Working Paper 3894, April 2006. p. 36

Sinavskaya (2005) О.В. Синявская НЕФОРМАЛЬНАЯ ЗАНЯТОСТЬ В СОВРЕМЕННОЙ РОССИИ: ИЗМЕРЕНИЕ, МАСШТАБЫ, ДИНАМИКА. (Non-formal employment in Russia measures, size and dynamics") Научные проекты НИСП — IISP Working Papers. WP5/2005/01.

Schneider, F. (2003): "The Size and Development of the Shadow Economies and Shadow 
Economy Labor Force of 22 Transition and 21 OECD Countries: What Do We Really Know?" in The Informal Economy in the EU Accession Countries: Size, Scope, Trends and Challenges to the Process of EU Enlargement, ed. by B. Belev: Center for the Study of Democracy, http://www.csd.bg/publications/infeconseeaccession/PART01.pdf.

Ukraine Jobs Study (2005). Fostering Productivity and Job Creation. (In Two Volumes) Volume II: Technical Chapters. Report No. 32721-UA. November 30, (World Bank)

UNECE (2005): "Towards a New European Model of a Reformed Welfare State: An Alternative to the United States Model," Economic Survey of Europe, Vol.:1, 105-114

World Bank (2000): "Making Transition Work for Everyone: Poverty and Inequality in Europe and Central Asia," The World Bank

World Bank (2006) "Ukraine: Creating Fiscal Space for Growth: A Public Finance Review". World Bank Report No. 36671 - UA. September 14, 2006 